\title{
FOTOS ENCONTRADAS EN EL ARCHIVO. APROXIMACIONES AL TRABAJO CON IMÁGENES A PROPÓSITO DE UN ÁLBUM AMATEUR SOBRE JUEGOS INFANTILES (ARGENTINA, FINES DEL SIGLO XIX) ${ }^{\alpha}$
}

\author{
Photos found in the archive. An approximation to the work with \\ images based on an amateur album about children's games \\ (Argentina, end of the $19^{\text {th }}$ century)
}

\section{Inés Dussel ${ }^{\mathrm{B}}$}

Fecha de recepción: 27/10/2018 • Fecha de aceptación: 16/12/2018

Resumen. El artículo presenta un estudio de una serie de fotos sobre juegos infantiles que se encuentra en el Archivo General de la Nación de Argentina. Parte del fondo de la Sociedad Fotográfica Argentina de Aficionados, activa entre 1889 y 1925, el álbum se compone de 77 imágenes de inusual calidad que presentan grupos heterogéneos de niños en espacios diversos en distintos juegos. Las fotos contienen escasa información sobre cómo fueron producidas, pero la investigación y análisis detallados revela distintos aspectos sobre la producción de imágenes de infancia en esa época. El texto presenta en primer lugar algunas consideraciones generales sobre el soporte fotográfico y sus postulados epistémicos como documentos históricos. En segundo lugar aborda la biografía social de estas fotografías, buscando indagar en la información disponible en sus inscripciones peritextuales para precisar sus condiciones de producción, autoría y circulación. A continuación, se introduce el análisis de algunos de los contenidos de estas imágenes, especialmente con relación a cómo estas imágenes, por sus opciones estéticas, colaboran en producir una

\footnotetext{
a Agradezco la ayuda de Luis Priamo para seguir el rastro de la Sociedad Fotográfica Argentina de Aficionados, y a Martín Schuliaquer por su apoyo con indagaciones posteriores en el AGN. También quiero agradecer a los archivistas del AGN por su eficacia en la búsqueda y su generosidad en compartir sus indagaciones sobre la historia del álbum, así como al personal de la Biblioteca Nacional de España donde se conservan algunas publicaciones de estas imágenes.
}

B Departamento de Investigaciones Educativas. CINVESTAV-IPN de México. Calzada de los Tenorios, 235. Col. Granjas Coapa, CP 14330. Ciudad de México. México. idussel@gmail.com (D) http://orcid.org/0000-00033983-3985

Cómo citar este artículo: Dussel, Inés. «Fotos encontradas en el archivo. Aproximaciones al trabajo con imágenes a propósito de un álbum amateur sobre juegos infantiles (Argentina, fines del siglo XIX)». Historia y Memoria de la Educación 10 (2019): 51-89 
nueva iconografía sobre la infancia. Finalmente, se reflexiona sobre las demandas éticas del trabajo con la fotografía, invitando a un estudio en profundidad que permita singularizarlas y que contribuya a redefinir otras políticas de archivo y de memoria en la historia de la educación.

Palabras clave: Historia visual de la educación; Fotografía amateur; Juegos infantiles; Archivo visual.

Abstract. This article presents a study of a series of photos on children's games that is preserved at the National General Archive in Argentina as part of the Fond of the Argentinean Photographic Society of Amateurs, active between 1889 and 1925. The album contains 77 pictures of unusual quality that present heterogeneous groups of children playing diverse games in different settings. The photos include little information about how they were produced, but a detailed research and analysis can reveal different aspects of the production of images of childhood at that time. The text presents, in its first part, some general considerations about photography as historical documents and its truth-claims; in the second part, it discusses the social biography of these images, looking at the available information in its peri-textual inscriptions to trace its conditions of production, authorship, and circulation, and introduces the analysis of some of its contents, particularly in relation to how these images, in their aesthetic choices, collaborate in the production of a new iconography of childhood. The final section raises some reflections about the ethical demands of working with photographs, calling for an in-depth study that makes room for their singularization and contributes to redefining the politics of the archive and of memory in the history of education.

Keywords: Visual history of education; Amateur photography; Children games; Visual archive.

Cada verdadero historiador sigue siendo un poeta del detalle, y hace sonar sin cesar, como el esteta [...], las mil armonías que una pieza rara despierta en un campo de conocimientos. ${ }^{1}$

¿Cómo trabajar las imágenes que se encuentran en el archivo histórico? En este artículo se propone una reflexión historiográfica en torno a una serie de fotografías sobre juegos infantiles que, si bien están disponibles en el Archivo General de la Nación Argentina (AGN) y han sido ocasionalmente utilizadas para ilustrar trabajos sobre la historia de

\footnotetext{
1 Michel De Certeau, La escritura de la historia (Ciudad de México: Universidad Iberoamericana, 2006), 85.
} 
la infancia en el 1900, hasta el momento no han sido estudiadas como conjunto. El hallazgo de esta serie se dio en el marco de un trabajo en curso sobre la historia de los uniformes escolares; el encuentro fortuito confirma lo que dice la historiadora Lila Caimari: «cada tanto, una pieza de[l ... archivo que late bajo el libro asoma triunfante, estelar, en el texto principal», ${ }^{2}$ y no queda relegada a la nota a pie de página.

Las fotografías, 77 en total, muestran con gran calidad y detalle distintos juegos infantiles en los que participan grupos diversos -incluyendo niños y niñas afroargentinos- en varios espacios: casas, escuelas, plazas o terrenos baldíos. Son parte de un fondo específico, el de la Sociedad Fotográfica Argentina de Aficionados, que fue donado al AGN en 1940. Fue claro desde el principio que, por su inusual calidad fotográfica y la riqueza semántica, esta serie era una pequeña gema, un tesoro. Sin embargo, la información disponible inicialmente era pobre: todas tienen uno, dos o tres números de inventario, fruto de distintas catalogaciones; un tercio de las fotos tienen fecha (febrero-septiembre 1902) y más de la mitad tienen título - el nombre de un juego-. ¿Cómo entender esta serie? ¿Cómo escuchar, siguiendo a de Certeau, las mil armonías que estas piezas pueden despertar en el campo de conocimientos sobre la historia de la educación y de la infancia?

La metáfora de la escucha puede parecer poco pertinente para el trabajo con imágenes, que convoca ante todo a la visión como sentido para aproximarse a su densidad y especificidad. Sin embargo, la escucha y el tacto apelan a un abordaje multisensorial, que permita indagar sobre lo que dice y transmite una imagen no solamente como texto sino también a través de sus silencios y de su propia presencia, aun cuando sea digital. Al respecto, es interesante traer el trabajo de Peter Szendy sobre la historia de la escucha, quien señala que la idea moderna de «la condescendencia del oído, que se presenta como la pura acogida de lo que viene», llegó después de muchas otras posibilidades de la escucha que no neutralizaban las marcas o puntuaciones propias y ajenas. ${ }^{3}$ Por ejemplo, Laënnec, autor del Tratado de la auscultación mediata en 1819, subrayaba la importancia

\footnotetext{
${ }^{2}$ Lila Caimari, La vida en el archivo. Goces, tedios y desvios en el oficio de la historia (Buenos Aires: Siglo XXI Editores, 2017), 9.

${ }^{3}$ Peter Szendy, En lo profundo de un oído. Una estética de la escucha (Santiago de Chile: Ediciones Metales Pesados, 2010), 60.
} 
de interponer un aparato (el estetoscopio) que pusiera distancia entre el cuerpo del médico y el del paciente. Para Laënnec, si no hay mediación, se corre el riesgo de no escucharse más que a sí mismo. Al revés: se escucha mejor marcando la escucha, planteando preguntas «literalmente con la punta de los dedos» - por eso los golpecitos con que se acompaña la auscultación. ${ }^{4}$ Para Szendy, la escucha está suspendida entre el tacto y la mirada, y necesita a ambos para acceder al sentido.

Siguiendo este hilo, este trabajo intenta escuchar lo que estas imágenes, sus armonías, sus barullos, sus silencios, pueden aportar a la historia de la educación. Para eso, se va a desplegar el abordaje historiográfico elegido en este estudio, todavía en curso, para aproximarse a la serie de fotografías, buscando evitar la reproducción del clisé fotográfico y la desidentificación de la fotografía que la subsume en estereotipos de infancia y de juegos. ${ }^{5}$ Para ello, se presentarán en primer lugar algunas consideraciones generales sobre el soporte fotográfico y sus postulados epistémicos e históricos; en segundo lugar, se abordará la historia social de estas fotografías, buscando indagar en la información disponible en sus inscripciones peritextuales; ${ }^{6}$ y en tercer lugar, se introducirá un primer análisis de algunos de los contenidos de estas imágenes, especialmente con relación a cómo estas imágenes contribuyen, por sus opciones estéticas, a producir una nueva iconografía sobre la infancia.

\section{LA FOTOGRAFÍA COMO DOCUMENTO HISTÓRICO}

Un primer eje de reflexión que propone este trabajo es sobre el tipo de documento histórico que constituyen las fotografías, y sobre las condiciones en que se constituyeron en signos legibles, autorizados y confiables en la modernidad. En una discusión sobre su carácter de «testimonio» o "captura» de un momento histórico particular, las historiadoras Lynn Hunt y Vanessa Schwartz señalan que

\footnotetext{
${ }^{4}$ Szendy, En lo profundo de un oído, 63. En tiempos digitales, es muy sugerente pensar en esta escucha de los dedos: una vuelta interesante sobre las tactilidades pre (y quizás post) cibernéticas.

5 Véase el trabajo de Sjaak Braster y María del Mar Pozo Andrés, «La Escuela Nueva en Imágenes: Fotografía y Propaganda en The New Era (1920-1939)", Historia y Memoria de la Educación 8 (2018): 97-145, para una discusión de la construcción de estereotipos visuales sobre la infancia, y de los efectos que esta des-identificación produce en la comprensión de los fenómenos histórico-educativos.

- Se trata de las inscripciones que están en los márgenes de las fotos: títulos, número de inventario, notas, fechas. Para la noción de peritextual, véase Gerard Génette, Umbrales (México DF: Siglo XXI, 2001).
} 
[L]a fotografía tuvo efectos profundos en la forma de pensar la relación entre la imagen y el mundo exterior representado en ella. [...] Los estudiosos empezaron a reinterpretar las imágenes hechas antes de la fotografía (ya fueran pinturas, esculturas, pinturas o tapices) a través de un imaginario fotográfico, suponiendo que la gente había intentado siempre representar lo real, de mejor o peor forma. ${ }^{7}$

Esta interpretación se impuso sobre otras posibilidades. Puede verse un ejemplo de los debates iniciales sobre el estatuto de la fotografía en el estudio de Thierry Gervais sobre la prensa ilustrada durante la guerra de Crimea en 1855. El trabajo de Gervais evidencia que los editores tenían, en ese momento, una relación problemática y ambigua con las fotografías de la guerra, y en la ilustración de las noticias preferían dibujos y pinturas como representaciones más útiles y más ajustadas de la realidad. ${ }^{8}$ En la perspectiva de los editores, las fotografías capturaban todo lo que estaba frente al lente, lo cual era percibido como una limitación; el dibujo, en cambio, podía apuntar a detalles y transmitir climas emocionales que se percibían como más próximos al acontecimiento. William Fox Talbot (1800-1877), uno de los primeros fotógrafos, dijo que la fotografía era «una ayuda mecánica para aquellos que carecen de talento para dibujar». ${ }^{9}$

Pocos años después, serían pocos los que dudarían de las ventajas de la fotografía frente a otros medios manuales de representación. Hacia finales del siglo XIX, la promesa de la fotografía de producir una «objetividad mecánica» ya tenía una amplia adhesión entre los investigadores. ${ }^{10}$ John Berger señaló que la cámara, el positivismo y la sociología crecieron juntos en el siglo XIX, y compartieron la creencia de que los hechos observables y cuantificables les ofrecerían a los seres humanos

\footnotetext{
${ }^{7}$ Lynn Hunt \& Vanessa Schwartz, «Capturing the Moment: Images and Eyewitnessing in History», Journal of Visual Culture 9, no. 3 (2010): 259. Todas las traducciones de los textos en inglés y francés son de la autora, a excepción de que se señale lo contrario.

8 Thierry Gervais, «Witness to War: The Uses of Photography in the Illustrated Press, 1855-1904», Journal of Visual Culture 9, no. 3 (2010): 370-384.

${ }^{9}$ Citado en Tom Gunning, «What's the Point of an Índex? Or, Faking Photographs», en Still Moving. Between Cinema and Photography, eds. Karen Beckman \& Jean Ma (Durham, NC \& London: Duke University Press, 2008), 27.

${ }^{10}$ Lorraine Daston \& Peter Galison, Objectivity (New York: Zone Books, 2007).
} 
un conocimiento completo y objetivo. ${ }^{11}$ Berger destacó que estos "postulados de verdad» de representar la vida en términos precisos y objetivos han sido centrales en los usos públicos de la fotografía, sobre todo en la investigación científica y el fotoperiodismo. Incluso Sigfried Kracauer, un lúcido analista del cine, dijo que «las fotografías tienen una indudable afinidad con la realidad no escenificada (unstaged reality)».12 Aun cuando los espectadores ya han (hemos) sido bien educados respecto a la imposibilidad de la «no escenificación» de las fotos, su afinidad con la realidad es una creencia todavía muy extendida, aún en la era digital. ${ }^{13}$

En el ámbito de la historiografía, sin embargo, el debate sobre estos postulados de verdad de la fotografía no ha cesado de crecer en los últimos años. ${ }^{14}$ Por un lado, se ha expandido la consideración de las fotografías como artefactos materiales, como entidades con su propia historia o biografía social, que juegan un rol activo en la producción de sentido en tanto actantes no humanos en las redes que configuran lo social. ${ }^{15}$ Esta perspectiva plantea que las fotografías no pueden ser pensadas por fuera de las trayectorias materiales y afectivas que marcan su vida como artefactos, y también su inscripción en políticas de archivo particulares. Este tipo de abordaje subraya la importancia de una consideración multisensorial de la fotografía. Señala Elizabeth Edwards: «[1]as fotografías son el resultado de caminar con cámaras, un sentido incorporado, corporal de la tecnología en tanto la cámara se vuelve, en efecto, un ojo-prótesis y la creadora de una prótesis de memoria, una memoria prostética, a través de la fotografía. Hay que tener en cuenta que distintas tecnologías

\footnotetext{
11 John Berger, «Appearances», en Another way of telling, eds. John Berger \& Jean Mohr (New York: Vintage Books, 1995), 81-129.

${ }_{12}$ Citado en Hunt y Schwartz, «Capturing the Moment», 259.

13 Como señala Tom Gunning, aunque lo digital da mucha libertad para manipular una foto y convertirla en algo distinto, todavía la fotografía «sigue siendo parasitaria del reclamo inicial de precisión contenida en algunos usos de la fotografía» (Gunning, «What's the Point of an Índex?», 27). Esto es, las transformaciones de una foto, su carácter lúdico, dependen de poder ser reconocidas como fotos; hay un "postulado de verdad» que mantiene su importancia en la producción y circulación de la fotografía digital.

14 Véase el trabajo de António Nóvoa, «Ways of Saying, Ways of Seeing: Public Images of Teachers (19th- 20th Centuries)», Paedagogica Historica 36, no. 1 (2000): 20-52, uno de los primeros que dio impulso a este debate.

${ }_{15}$ Inés Dussel \& Karin Priem, "The visual in histories of education: A Reappraisal», Paedagogica Historica 53, no. 6 (2017), 641-649.
} 
de cámaras demandaban formas distintas del movimiento». ${ }^{16}$ Este enfoque permite volver a imaginar, en la foto, el cuerpo que estaba detrás, el cruce de miradas, la voz que disponía la escena, el peso o la magnitud de esa cámara en una escena concreta. También permite volver a preguntarse por qué unas fotos sobreviven y no otras; cuáles fueron las políticas, procedimientos y cuerpos que decidieron guardar ciertos registros y qué pasó con esas decisiones en el curso del tiempo. Por eso, para Edwards, hay que considerar la historia de la fotografía como parte de una «historia afectiva y efectiva», esto es, de la concreción y las estrategias de historias particulares que conectan artefactos, personas y afectos en modos plurales y cambiantes a lo largo de la historia. ${ }^{17}$

Por otro lado, el cuestionamiento a la noción de fotografía como evidencia histórica transparente y no mediada también se basa en una reconsideración de la relación de la fotografía con el tiempo. La emergencia de la fotografía, un medio que define sus imágenes por el fragmento de tiempo que la película o el sensor digital está expuesto a la luz, «reveló el nuevo poder humano de capturar instantes de tiempo específicos» ${ }^{18}$ y archivarlos para futuros espectadores. Como medio basado en el tiempo, la fotografía apareció como un signo que traía el pasado al presente, y expandía la temporalidad del presente por la presencia de fragmentos activos del pasado. La fotografía, junto con el cine, colocó nuevos estándares de "precisión, memoria, cognoscibilidad ${ }^{19}$ para cualquier registro de la cultura. Pero también inició la difusión del impulso archivístico, la presión para registrar la vida y para guardar esos registros como unidades separadas y aisladas — una especie de liberación del deseo de archivo que continúa ampliándose con los medios digitales.

En estas nuevas perspectivas historiográficas, la fotografía como documento histórico ya no es considerada como la vía de entrada a un

${ }^{16}$ Elizabeth Edwards, «Out and About: Photography, Topography, and Historical Imagination», en Double Exposure: Memory and Photography, ed. Olga Shevchencko (London: Transaction Press, 2014), 190.

${ }_{17}$ Elizabeth Edwards, «Photography: A Strong History?», en Photo Archives and the Idea of the Nation, eds. Constanza Caraffa \& Tiziana Serena (Berlin: Walter De Gruyter, 2015), 325.

${ }_{18}$ Nicholas Mirzoeff, How to See the World. A Pelican Introduction (London: Penguin Books, 2015), 23.

19 Mary-Ann Doane, The Emergence of Cinematic Time. Modernity, Contigency, the Archive (Cambridge, MA: Harvard University Press, 2002), 24. Véase también Kathryn Yacavone, Benjamin, Barthes, and the Singularity of Photography (New York \& London: Bloomsbury, 2013). 
encuentro directo e inmediato entre presente y pasado. La investigación de los documentos fotográficos supone adentrarse en una combinación de tecnologías, impulsos archivísticos, signos y cuerpos que portan miradas y temporalidades heterogéneas. La historiadora francesa Arlette Farge plantea que las fotografías son "el latido del tiempo» que recuerdan que había un futuro en el pasado que se está viendo; son heridas del tiempo, pasajes, breves llamados, como cuando se perciben detalles pasajeros que abren conexiones entre el presente y los mundos que ya han sido enterrados y desaparecidos. ${ }^{20}$ La noción de "herida del tiempo» resiste la tiranía del régimen de plena visibilidad (tout-plein), que niega los quiebres y ausencias en la conexión con los registros del pasado; ${ }^{21}$ por el contrario, afirma la necesidad de tomar en cuenta tanto la historicidad compleja de los registros como el vínculo epistémico y afectivo de los investigadores con sus fuentes, que está atravesado por múltiples dinámicas.

\section{LA INVESTIGACIÓN SOBRE EL ÁLBUM AMATEUR SOBRE JUEGOS INFANTILES}

A partir de estas consideraciones sobre la complejidad de la fotografía como documento histórico, tanto por su propia trayectoria de producción y archivo como por las relaciones que los historiadores tienen con los registros en distintos momentos históricos, se abren entonces distintas vías para el trabajo con las imágenes de archivo.

Además de los trabajos de Elizabeth Edwards ya mencionados y de los aportes de Deborah Poole sobre la economía visual en los Andes, que estudia los circuitos de producción, circulación y consumo de imágenes en esa región, ${ }^{22}$ un antecedente relevante para la aproximación elegida

${ }^{20}$ Arlette Farge, «Le temps logé en la photographie. À partir de Barthes et Kracauer», Intermédialités 7 (2006): 206 y 213.

${ }_{21}$ Sylvie Lindeperg, La voie des images. Quatre histoires de tournage au printemps-été 1944 (Paris: Verdier, 2013), 13.

22 Deborah Poole, Vision, Race and Modernity. A Visual Economy of the Andean Image World (Princeton, NJ: Princeton University Press, 1997). Desde una perspectiva neomarxista y postcolonial, Poole estudió las prácticas materiales involucradas en estos circuitos, por ejemplo los ateliers fotográficos, la producción de postales (tal como lo hacen Antonio Viñao y su equipo), los pintores, los creadores de operetas en el siglo XVIII sobre los Incas, con una lente particular sobre cómo se produjo visualmente una noción racial de la identidad andina, y las condiciones históricas, cambiantes, para la producción de la diferencia racial. Poole subraya la relevancia de estudiar cómo 
es el trabajo de Fernando Aguayo y Alejandra Padilla Pola sobre fotografías mexicanas de fines del siglo XIX. Los autores señalan que el estudio de las fotografías de archivo tiene que tener en cuenta tres cuestiones: «mirar las inscripciones impresas o manuscritas ubicadas en los soportes primarios», recuperar «información vía la investigación en los periódicos y distintas fuentes de época, así como los itinerarios biográficos» de los fotógrafos, y atender «a la información contenida en la propia imagen». ${ }^{23}$ Estas tres cuestiones, unidas a teorizaciones sobre la historicidad de la tecnología fotográfica y la vida material de las imágenes, resultan fértiles para ampliar el análisis de la serie considerada, como se verá a continuación. En este apartado, se presentan los caminos tomados para la investigación de la serie de fotografías sobre juegos infantiles hallados en el AGN de Argentina: la indagación sobre sus formas de producción, autoría y circulación, y el análisis de los contenidos de las imágenes, que remiten a la construcción de discursos visuales sobre la infancia a fines del siglo XIX.

\section{Producción y circulación del álbum}

Como ya fue señalado, las fotografías son parte del Fondo de la Sociedad Fotográfica Argentina de Aficionados (SFAdeA), activa entre 1889 y 1925, fondo que llegó al AGN en 1940 por donación de la Casa Witcomb, un atelier de fotografía que cerró en esa fecha y donó su colección al AGN. ${ }^{24}$ En un sentido, son objets trouvés, objetos encontrados de los que no se sabe mucho y que aparecen separados de sus contextos de producción. Pero si los objets trouvés son los que han sido retirados de

\footnotetext{
las razas y las clases sociales como producciones visuales, siguiendo el rastro de los que producen las imágenes, pero también a las propias imágenes en sus poderes y debilidades, sus silencios e inconsistencias.

${ }^{23}$ Fernando Aguayo y Alejandra Padilla Pola, «Fotografía y ciudad», en «Instantáneas» de la Ciudad de México. Un álbum de 1883-1884, eds. Alicia Salmerón y Fernando Aguayo (Ciudad de México: Instituto Mora/Universidad Autónoma Metropolitana-Cuajimalpa, 2013), 41 y 43.

${ }^{24}$ Los archivos de la SFAdeA están ubicados en varios lugares, pero el AGN es que tiene la mayor parte (46 álbumes), aunque también hay otros álbumes en el Museo de la Ciudad de Buenos Aires, Museo Histórico Nacional, Academia Nacional de Bellas Artes, Museo Mitre y Biblioteca Manuel Gálvez. Véase Verónica Tell, «Gentlemen, gauchos y modernización. Una lectura del proyecto de la Sociedad Fotográfica Argentina de Aficionados», Caiana. Revista de Historia del Arte y Cultura Visual del Centro Argentino de Investigadores de Arte (CAIA) 3 (2013):16. Disponible en: http://caiana.caia. org.ar/template/caiana.php?pag=articles/article_2.php\&obj=110\&vol=3
} 
los circuitos de exhibición y circulación, ${ }^{25}$ entonces estas fotos no cumplen esa condición, porque no han sido marginales sino que han estado integradas en distintos relatos sobre la historia de la educación y la infancia argentinas. Sin embargo, su aparición en el marco de políticas de archivo que las han puesto a disposición, digitalizadas, para la consulta del público, que permiten copiarlas y trasladarlas a otros ámbitos pero —al menos hasta el momento- no permiten consultar los álbumes originales por temor a que se dañen, podría decirse que contribuye a convertir los registros visuales en objets trouvés, objetos enterrados en volúmenes parahumanos de datos y bits que constituyen los archivos oficiales y no oficiales de la era digital. En esa circulación, la separación, la fragmentación, la descontextualización radical y el mash-up corren el riesgo de producir nuevas formas de amnesia colectiva. ${ }^{26}$ Intentar restituir una singularidad a este corpus, identificar sus condiciones de producción y rastrear sus formas de circulación iniciales son modos de ir contra esta "tempestad que sopla desde la tierra del olvido», al decir de Walter Benjamin. ${ }^{27}$

Algunas fotografías tienen inscripciones que, aunque escuetas, son valiosas para comenzar a analizar cuándo y cómo fueron producidas. Se mencionó anteriormente que 45 de estas imágenes incluyen un título (el nombre del juego que juegan los niños), y 22 tienen una fecha (mes y año, de febrero a septiembre de 1902). En esta última notación, aparece una inscripción, "CyC», que se infirió - correctamente- que refería a la revista ilustrada Caras y Caretas, editada en Buenos Aires entre 1898 y 1941. ${ }^{28}$ En esta revista fue posible hasta el momento encontrar nueve artículos donde están publicadas las fotografías, incluyendo uno editado el 10 de enero de 1903 que no está consignado en las inscripciones peritextuales de las fotografías del AGN. En total en esa publicación se incluyeron 24 fotografías del álbum. Un hallazgo relevante es que hay tres fotografías publicadas cuyo original no está en el AGN («Sir Roger»

\footnotetext{
${ }^{25}$ Propio del found footage son imágenes halladas fuera del circuito de exhibición que son introducidas en éste a través de la apropiación artística. Marcos Pererneau, "Construcción de la referencia», en Antología de Argumentos teatrales en Argentina, 2003-2013 (Buenos Aires: Libretto, 2015), 17.

${ }^{26}$ Georges Didi-Huberman, «L'image brûle» en Penser par les images, Laurent Zimmermann, George Didi Huberman, et al. (Nantes: Editions Cécile Defaut, 2006), 11-52.

${ }^{27}$ Walter Benjamin, «Franz Kafka. On the Tenth Anniversary of his Death», en Illuminations. Essays and Reflections (New York: Schocken Books, 1968), 138.

${ }^{28}$ Caras y Caretas incluyó fotografías desde sus primeros números. Véase Jorge Rivera, "Caras y Caretas: La economía literaria del mercado», La Nación Suplemento Literario, 15 de marzo de 1990: 1.
} 
—CyC 190/1902 , «Balancín-balanzas» - CyC 207/1902-y «La payana», СуC 223-1902).

En el marco de la investigación en distintos archivos de Argentina y España, y siguiendo las referencias del trabajo de Edgardo Ciafardo sobre la historia de la infancia en Buenos Aires, ${ }^{29}$ se encontró una publicación anterior de las fotografías en Buenos Aires-Revista Semanal Ilustra$d a$ entre enero y agosto de 1897, la que hasta el momento parece ser la primera publicación de esta serie. ${ }^{30}$ Esto permite datar a este conjunto de fotografías no en 1902, como dice la notación de archivo, sino en algún momento entre 1889, año de fundación de la SFAdeA, y 1896, ya que la primera publicación encontrada es del 3 de enero de 1897.

En la revista Buenos Aires se publicaron 18 fotos de las 77 del álbum, además de la mencionada "La payana», no disponible en el AGN. Es importante notar que tanto en Caras y Caretas como en Buenos Aires las fotografías se acompañaban de textos donde se relataban los juegos, ficcionalizando las escenas fotográficas y en algunos casos describiendo las reglas o procedimientos de los juegos retratados. Sin embargo, puede notarse que en dos números de 1897 de la revista Buenos Aires se publicaron las fotografías como ilustración independiente, sin texto narrativo (un total de cinco fotografías sin relato adjunto). Considerando las dos revistas, se publicaron 31 fotos de las 77 que componen el álbum, ${ }^{31}$ así como otras tres fotografías que parecen haber formado parte del álbum inicial pero no se conservan en el AGN. Considerando que las 77 fotos incluyen fotos que repiten la misma escena o juego (por ejemplo, tres fotos de una misma escena del juego ta-te-ti), puede señalarse que buena parte del álbum llegó a difundirse a públicos amplios.

¿Qué más puede inferirse a partir de las inscripciones peritextuales? Los títulos de las fotografías son en todos los casos descriptivos de las escenas que se muestran; están escritos en tinta, junto con tres números

\footnotetext{
${ }^{29}$ Edgardo Ciafardo, Los niños en la Ciudad de Buenos Aires (1890-1910) (Buenos Aires: CEAL, 1992).

${ }^{30}$ La publicación Buenos Aires. Revista Semanal Ilustrada fue editada entre 1895 y 1899, dirigida por José María Drago y luego por Gabriel Cantilo. Según la nota necrológica de José María Gutiérrez, se trató de una derivación del diario La Nación.

${ }^{31}$ La investigación sobre este corpus continuará con otras revistas ilustradas del período, entre ellas una revista publicada en Barcelona, La Ilustración Artística, que incluía fotografías de la SFAdeA.
} 
de inventario (uno de cuatro dígitos, otro de cinco dígitos que comienza con una $\mathrm{D}$ y un tercero de seis dígitos, que comienza con la notación Inv., que es el que se consigna como notación apropiada). ${ }^{32}$ Todas las notaciones parecen ser del mismo momento, con idéntica caligrafía y tinta. En algunas imágenes digitalizadas, con un marco exterior más amplio que el promedio, es posible ver una inscripción del álbum que dice «Juegos Infantiles Buenos Aires Antiguo». En tres fotografías hay notaciones en el margen superior derecho escritas en lápiz $(15,17,19)$ que remiten a páginas del álbum original. ${ }^{33}$

Para el análisis de los títulos, puede compararse la notación que figura en el AGN y los que aparecen en las revistas. La mayoría de los títulos en el AGN repite los de Caras y Caretas, aunque hasta el momento no se sabe cuál fue la original. Un caso significativo de cambio de título es la foto «Contando cuentos» (Inventario 214905), que muestra a un grupo mixto de niñas y niños escuchando a una niña mayor que habla, que en Caras y Caretas se tituló «Haciendo cuentas» (CyC 199, 1902). Si se comparan los títulos con los de la revista Buenos Aires, hay dos diferencias notorias: una imagen que tiene el mismo título ya señalado, pero muestra a un conjunto de niños, "Contando cuentos» (Inventario 214940) (véase figura 1), que en la revista Buenos Aires está incluido en un relato que se llama «Los raboneros», y «Lucha» (Inventario 214901), que en la revista Buenos Aires se llama «Un concurso y un jurado». En los dos casos, se trata de escenas callejeras de niños y muchachos, que tendieron a ser moralizados con el correr de los años.

\footnotetext{
32 La notación que parece ser más vieja, que va del número 994 al 1085, salta del 1060 al 1080. Si esta notación viniera de los álbumes originales, esto indicaría que faltan al menos 20 fotos de la colección original, lo que es consistente con el hallazgo de tres fotos publicadas cuyo original no se preservó en el AGN.

${ }^{33}$ Las inscripciones están siendo analizadas por el personal del Departamento Fotográfico del AGN. El signo D indica, en la notación interna, que la catalogación era previa a su ingreso al AGN, y el prefijo «Inv.» fue incorporado por el personal del archivo en la década de 1960. Los títulos del álbum («Buenos Aires Antiguo - Juegos Infantiles») también es probable que hayan sido incorporados en ese momento. En el reverso de las fotos es muy probable que no haya nada, pero hasta ahora no se sabe porque están pegadas a un álbum; se está analizando cómo despegar algunas sin dañarlas. El personal del AGN, considerando la historia de las colecciones y las catalogaciones, presume dos hipótesis más: que se mantuvo el orden con el que llegó el material y no se armaron nuevos álbumes, aunque pareciera haber fotos que no están en el espacio que les correspondía originalmente; y que los álbumes fueron armados en la Casa Witcomb, adonde fueron donados por la SFAdeA en 1925, dado que los álbumes tienen una estética similar a otros del mismo Fondo Witcomb. En todo caso, esta es una historia que continuará siendo escrita, porque su desvelamiento exige el trabajo coordinado de historiadores, archivistas, fotógrafos y conservacionistas.
} 


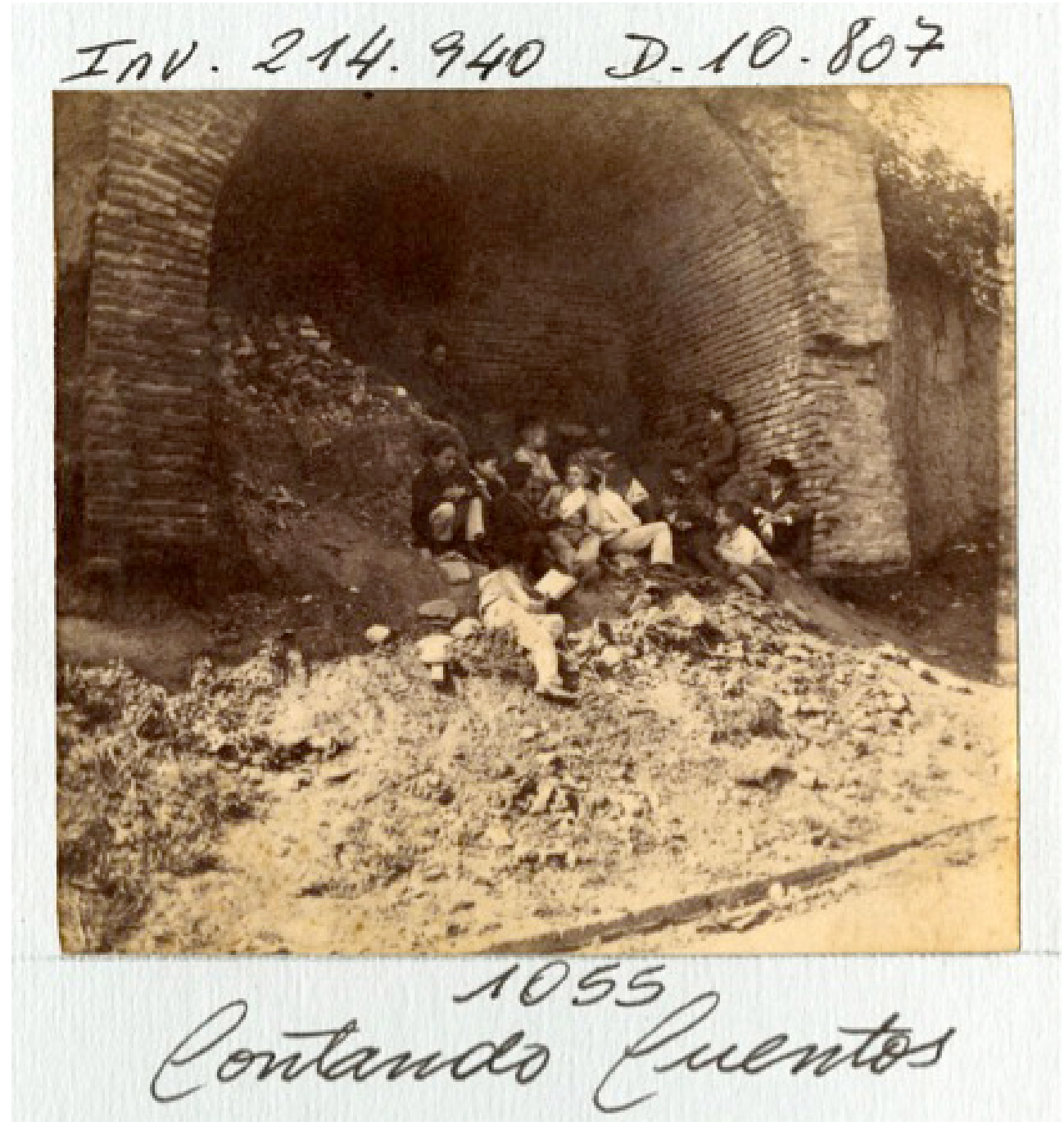

Figura 1. Contando cuentos. Argentina Archivo General de la Nación Dpto. Doc. Fotográficos, AR_AGN_DDF/Consulta_INV:214.940.

En los casos de fotografías no publicadas, como ya fue señalado, muchas de ellas son parte de la misma secuencia o escena, con ligeras modificaciones (en general, una posición distinta de alguno de los participantes). En esos casos, los títulos se repiten con los de la imagen publicada en Caras y Caretas. En otros casos, como «Boxeo», «Buen día 
su señoría» o «Barrilete», ninguna de las cuales fue publicada, parecen ser descripciones de los juegos que se observan en la fotografía. Hasta el momento no se sabe si los títulos eran los originales de las fotografías o si fueron agregados en la catalogación del AGN en la década de 1960 (véase nota 33 ). ${ }^{34}$

\section{Autoría/s: La fotografía amateur y la Sociedad Fotográfica Argentina de Aficionados (SFAdeA)}

¿Qué puede saberse del o los fotógrafos? En Buenos Aires-Revista Semanal Ilustrada y en Caras y Caretas, la mayor parte de las fotografías aparecen consignadas como autoría de Juan M. (¿Miguel?) ${ }^{35}$ Gutiérrez, quien fuera secretario de la SFAdeA (figura 2). Juan M. Gutiérrez era miembro de una familia patricia porteña, pero hasta el momento no ha sido posible confirmar si era sobrino ${ }^{36}$ de José María Gutiérrez (18311903), presidente del Consejo Nacional de Educación, el segundo personaje más importante entre las autoridades educativas después del Ministro. Sin embargo, como se verá más abajo, las fotos del álbum tienen distintos estilos y locaciones, y no es claro que todas tengan el mismo autor.

\footnotetext{
${ }^{34}$ Una pista para rastrear la fecha en que se titularon las fotos es buscar si los nombres de los juegos eran comunes en la fecha en que se produjeron las fotografías (entre 1889 y 1896). La búsqueda en Google Ngram Viewer, un software que permite ver cuándo se usa una expresión en las publicaciones impresas disponibles digitalmente, arroja que los títulos más representativos (ta-te-ti, rayuela, sillita de oro, Martín Pescador) eran comunes a fines del siglo XIX. Algunos libros de la época, como el del P. Santos Hernández, S.J., Juegos de los niños en las escuelas y colegios (Madrid: Editorial Saturnino Calleja, 1876), incluyen buena parte de los juegos retratados en las fotografías. Es decir, esta pista no contribuye a poder determinar con más precisión si los títulos fueron puestos en una fecha cercana a la producción del álbum o si son posteriores.

${ }^{35}$ La única fuente que identifica a Juan M. Gutiérrez como Juan Miguel es Juan Gómez, La Fotografía en la Argentina. Su Historia y Evolución en el Siglo XIX, 1840-1899 (Temperley: Abadía Ediciones, 1986), 138. En las fotografías y notas publicadas en distintos medios no aparece más que la inicial de su segundo nombre.

${ }^{36}$ En las notas necrológicas de José Ma. Gutiérrez, se hace mención a dos hijos del presidente del CNE, Ricardo y José María, y a cinco hijas mujeres (Julia, María Elena, Lucía, Ana Rosa y Luisa) («Dr. José María Gutiérrez, Anoche», La Nación, Domingo 27 de diciembre de 1903). Se menciona en otras notas de periódicos la presencia de Juan Miguel Gutiérrez, sin aclarar el parentesco con el extinto político. Véase la publicación especial de El Monitor de la Educación Común, órgano del Consejo, el 15 de enero de 1904 (Año XXIV, Tomo XIX, No. 371) que recopila las notas necrológicas y mensajes de pésame a la familia.
} 


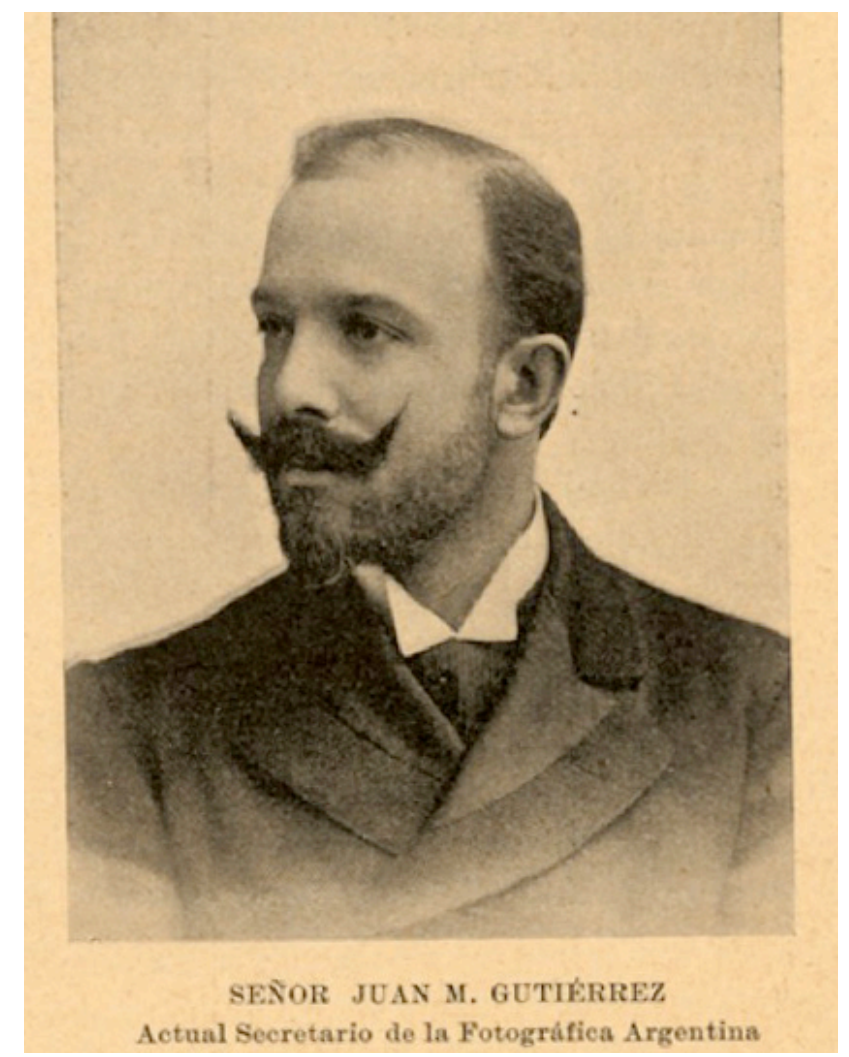

Figura 2. Señor Juan M. Gutiérrez. Fotografía incluida en la nota «La Sociedad Fotográfica Argentina», Buenos Aires. Revista semanal ilustrada III, No. 129 (26 de septiembre de 1897): 6.

En todo caso, saber que estas fotografías fueron parte del proyecto de la SFAdeA y que, al menos en parte, fueron producidas por uno de sus socios más encumbrados, es una pieza importante del rompecabezas que implica reconstruir su historia. Hay que tener en cuenta que, en la Argentina, la fotografía como práctica urbana distintiva estaba creciendo significativamente. En 1893 se publicó por primera vez la Revista Fotográfica Ilustrada del Río de la Plata, que contenía, además de numerosas propagandas, artículos dirigidos a quienes quisieran iniciarse en la fotografía, la mayoría traducciones de originales franceses. ${ }^{37}$ Una

\footnotetext{
37 La revista fue editada por Enrique Lepage (dueño de una casa fotográfica) y dirigida por Francisco Pociello, jefe de Taquígrafos de la Cámara de Diputados de la Nación. Véase Gómez, La Fotografía en la Argentina, 127-128.
} 
muestra de esta difusión puede encontrarse en las memorias de Vicente Quesada, renombrado historiador argentino, publicadas en 1889, que incluyen un texto titulado «Mi retrato», que hace referencia a «los numerosísimos establecimientos fotográficos en toda la capital». Para el autor, esto no era motivo de celebración: se trataba de un «contagio nervioso fotográfico» que hacía que todos quisieran sacarse un retrato o pidan un retrato para su álbum. Calificaba a este impulso como «una plaga»: «es preciso retratar al niñito, ipobrecito! Y la otra, y en fin, no se puede hacer distinciones entre los hijos. Como si esto no bastara, fotografían a los perros y los estancieros los caballos de raza, la marea sube y por ese aumento día a día los establecimientos fotográficos». La fotografía también era un "arma oficial defensiva», ya que se retrataba a reos, ladrones, y cada comisario tenía su álbum. Quesada terminaba su ensayo diciendo: «Esta dichosa fotografía... nos está volviendo loco a todos».38

Más allá de la queja y la ironía de Quesada, puede verse en estos relatos, coincidentes con otros de la época, ${ }^{39}$ cómo la fotografía amateur, en la que se inscribe el álbum estudiado, se ubica en un contexto de interacción creciente entre la profesionalización y comercialización de la fotografía por una parte, y por la otra la difusión de la práctica fotográfica en la población. Es importante notar que la noción de fotografía amateur es amplia y en muchos casos equívoca. Anne-Marie Garat señala que «la fotografía amateur es un mundo multifacético de una diversidad extraordinaria, que va desde los fotógrafos familiares a semi-profesionales, de cazadores casuales a miembros dilectos de clubes fotográficos locales».40 La fotografía amateur se difundió rápidamente en esos años, impulsada, entre otros, por las compañías fotográficas. Trabajos como los de Albert Londé, cuyo libro La Photographie Moderne (1888) fue rápidamente traducido al español, y los folletos de Eastman Kodak (1905) contribuyeron a expandir la práctica fotográfica en el público en general;41 por otra parte, estos trabajos

\footnotetext{
38 Vicente Quesada, «Mi retrato», en Memorias de un Viejo (1889), citado por Juan Gómez, La Fotografía en la Argentina, 145 y 147.

${ }_{39}$ Pueden verse relatos similares publicados en la prensa periódica en esos años en Verónica Tell, El lado visible. Fotografía y progreso en la Argentina a fines del siglo XIX (San Martín, UNSAM EDITA, 2017), 209-218.

40 Anne-Marie Garat, Found Photography (London: Thames and Hudson, 2013), 1-2.

41 Véase, entre otros, Alberto Londe, La fotografía moderna. Práctica y aplicaciones (Madrid: Fuentes y Capdeville, 1889) (Edición facsimilar- Sevilla: Extramuros, 2007), y The Modern Way in Picture Making. Published as an Aid to the Amateur Photographer (Rochester, NY: Eastman Kodak Company, 1905). Un estudio de la fotografía amateur y sus vínculos con la difusión de la práctica fotográfica
} 
acercaban a los fotógrafos profesionales y los amateurs, haciendo fluidos los circuitos de circulación de saberes sobre la fotografía. Otro historiador francés de la fotografía señala:

La generalización del término amateur a partir de 1880 y hasta la década de 1930 no debe confundirnos, ya que abarca realidades muy distintas. Desde 1890, la publicidad de Kodak [Women Who Use Kodak, 1891] se dirige a amateurs sin conocimientos técnicos, sobre todo a un nuevo público femenino, e incluso infantil, y a menudo reduce la práctica fotográfica al simple hecho de pulsar un botón. Al mismo tiempo, la aparición de un nuevo género de edición fotográfica —el manual básico- define un perfil ligeramente distinto: el burgués, más bien culto, que toma la fotografía como un hobby, deseoso de dominar los principales conocimientos técnicos y que evoca, en muchos aspectos, la figura del gran amateur de los primeros tiempos del medio, cuarenta años antes. Este último perfil de aficionado suele afiliarse a asociaciones. A pesar de que aún son escasas en Francia a principios de 1880, en 1907 ya existen más de 120.42

En los países europeos habían surgido dos tipos de instituciones diferentes en torno a la fotografía: unas establecidas tempranamente y que abordaban la investigación, las aplicaciones científicas y técnicas (Société Française de Photographie, Royal Society of London) y otras más tardías (en las décadas de 1880 y 1890) que, considerando la fotografía como arte, apuntaban al desarrollo de aspectos estéticos (Photo Club de Paris, The Linked Ring). En el caso argentino no existió esa distinción, siendo la Sociedad de Aficionados la única institución fotográfica que desarrolló su actividad dentro de la práctica no profesional. ${ }^{43}$ Pero su trabajo puede ser asimilado a lo que Elizabeth Edwards identifica para Inglaterra en relación con las sociedades y clubes de fotógrafos amateurs ingleses, cuya labor, organizada a través de encuestas y estudios fotográficos, contribuyó a producir visualmente la imaginación histórica y geográfica sobre Inglaterra. ${ }^{44}$

\footnotetext{
puede verse en Paul Spencer Sternberger, Between Amateur and Aesthete: The Legitimation of Photography as Art in America, 1880-1900 (Albuquerque, NM: University of New Mexico Press, 2002).

42 Quentin Bajac, La fotografía. La época moderna, 1880-1960 (Barcelona: Blume, 2015), 18-19.

${ }^{43}$ Véase Tell, «Gentlemen, gauchos y modernización», 15.

${ }^{44}$ A través de seguir el rastro de los clubes, sus publicaciones, sus viajes, sus lecturas, sus argumentos verbales y sus prácticas fotográficas, Edwards releva las prácticas de producción, reproducción y exhibición
} 
La SFAdeA pertenece a la categoría de los clubes selectos — de hecho, una investigadora los llamó los «gentlemen fotógrafos».45 Estuvo activa entre 1889 y 1925, y tuvo su pico máximo de actividad alrededor de 1910, llegando a tener hasta 600 socios. ${ }^{46}$ Fue fundada por hombres ricos, que abrazaron la fotografía amateur como parte de una renovación política y social, y participaron del impulso archivístico de finales del siglo XIX y comienzos del XX, buscando construir registros para el futuro. Sus fotografías tenían tanto un aire de documentalismo social, registrando la pobreza y los distintos tipos sociales, como un pictorialismo que quería producir un imaginario nacional renovado que mostrara el liderazgo continental argentino «imitando y asimilando en todo a las principales Naciones de la Europa», como decían en su Asamblea General de 1899.47

La SFAdeA combinaba actividades vocacionales con comerciales, como la venta de álbumes temáticos, de los que se conservan 46; el de juegos infantiles es el número $30 .{ }^{48}$ Muchos de sus socios eran hombres de Estado; no es casual, entonces, que pensaran en esta producción de registros como la producción de una memoria visual de la Argentina, de una iconografía nacional moderna tecnológicamente pero también atenta a lo distintivo del país, que se identificaba con lo gauchesco. Los fotógrafos de la Sociedad no se veían como artistas ni como fotógrafos comerciales; tenían más bien espíritu de reporteros y también de historiadores. ${ }^{49}$ Los socios

\footnotetext{
de las imágenes las vidas de aquellos que las produjeron y a las formas en que circularon, y las estructuras de sentimiento o de afectos que estaban implicadas en la «sobrevida» de las imágenes en libros, asociaciones y sobre todo en las iconografías nacionales. Elizabeth Edwards, The Camera as Historian. Amateur Photography and Historical Imagination, 1885-1918 (Durham, NC: Duke University Press, 2012).
}

${ }^{45}$ Véase Tell, El lado visible, 139-156. El término es un préstamo de lo que David Viñas describió para los escritores de la época, a quienes llamó los «gentlemen escritores». Véase su trabajo Literatura argentina y realidad política, editado originalmente en 1964 y reeditado por el Centro Editor de América Latina en 1994.

46 Abel Alexander \& Luis Priamo, «Notas sobre la fotografía porteña del siglo XIX», en Buenos Aires, Memoria Antigua. Fotografías 1850-1900, ed. Luis Priamo (Buenos Aires: Fundación CEPPA Ediciones, 2018), 9-27.

47 Gómez, La Fotografía en la Argentina, 144.

48 Marta Mirás, Imágenes del espacio público. Buenos Aires 1900 (Buenos Aires: Instituto de Arte Americano e Investigaciones Estéticas, 2001). Debe notarse que el término álbum no es necesariamente «el de un objeto preciso», es decir, «un artefacto que contiene un grupo cerrado de imágenes». Se lo usaba para designar «una forma de comercializar grupos de fotografías». Aguayo y Padilla Pola, «Fotografía y ciudad», 38.

49 Luis Priamo, «La Sociedad Fotográfica Argentina de Aficionados y sus fotografías nacionales». Ponencia en el I Encontro de História da Fotografía Latino-Americana Gilberto Ferrez, Río de Janeiro, Brasil (1997), 9. 
más prominentes de la Sociedad retrataron ante todo gauchos y escenas del campo, acorde con la producción de un imaginario nacional centrado alrededor del dominio pampeano, ganadero, sobre otras actividades y posibilidades; también se entusiasmaron con las muestras de modernidad urbana (ver figura 3). Tradición y progreso material pueden considerarse dos de los organizadores centrales de sus series fotográficas. ${ }^{50}$

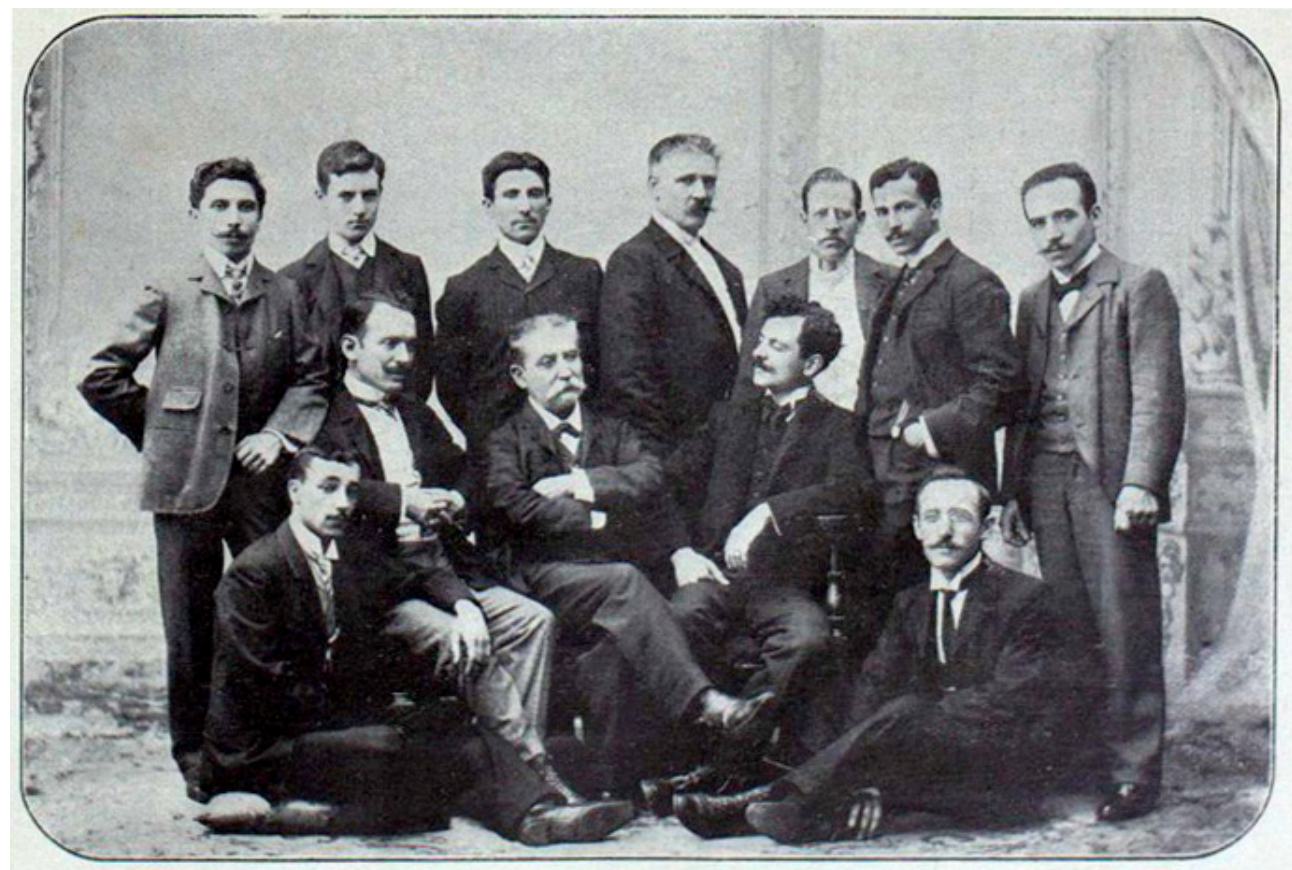

GRUPO DEL PERSOSAL DE EMPLEADOS DE IA SUCIEUAD FUTOGRAFLA ARGESTISA DE AYICHSADUS

Figura 3. Grupo del personal de empleados de la SFAdeA. Fotografía incluida como parte de «El primer acontecimiento artístico de 1904», La ilustración sudamericana. Revista Ilustrada de las Repúblicas Sud-Americanas XII, Nos. 265-266 (enero 1904): 21.

\footnotetext{
${ }_{50}$ Alexander \& Priamo, «Notas sobre la fotografía porteña del siglo XIX», 24. Si bien excede al alcance de este trabajo, hay que notar, con Luis Priamo y otros investigadores, que el trabajo de la SFAdeA fue pionero en entronizar una imagen idílica de lo gauchesco, que en 1913 tendría su consagración definitiva con las conferencias de Leopoldo Lugones, considerado entonces el poeta nacional, sobre el poema de José Hernández Martín Fierro. Puede observarse esta construcción discursiva, más modernizadora que la de Lugones, en las fotografías que Francisco Ayerza y Leonardo Pereyra prepararon para un libro ilustrado sobre el poema de Hernández que nunca se imprimió. Ver Priamo, «La Sociedad Fotográfica Argentina de Aficionados y sus fotografías nacionales»; Tell, El lado visible; Julieta Pestarino, «La imagen fotográfica bajo la mirada antropológica. El caso de la Sociedad Fotográfica Argentina de Aficionados», XI Jornadas de Sociología. Facultad de Ciencias Sociales, Universidad de Buenos Aires, Buenos Aires, 2015.
} 
En sus estatutos señalaban que, si se disolvía la sociedad, todos sus archivos debían donarse a museos o bibliotecas del estado. Sin embargo, por motivos que no son del todo claros, cuando la sociedad se disolvió en 1925 sus archivos pasaron a la Casa Witcomb, una casa privada de fotografía; fue en 1939-1940, ante el cierre de este estudio, que ingresaron al Archivo General de la Nación, apenas creado, donde actualmente se conservan 4.600 negativos de vidrio de $18 \times 24 \mathrm{~cm}$ y estereoscópicos de $8 \times 16 \mathrm{~cm}$, que debían haber sido los tamaños reglamentarios para los socios. ${ }^{51}$

La pertenencia a la SFAdeA explica por qué las fotos no estaban firmadas. El estatuto de la SFAdeA impedía que se asociaran a ella los fotógrafos profesionales, algo que debía estar relacionado a su clase social. ${ }^{2}$ Por ello, se comprometieron a una autoría colectiva y no podían firmar sus fotos ni conservar los negativos, que debían entregarse a la Sociedad..$^{53}$ La excepción son las fotos que se publicaron en periódicos o revistas; en el caso de Caras y Caretas, se sabe que la revista pedía un pie de página o epígrafe y el nombre del autor, aunque no siempre lo consignaba. ${ }^{54}$

Como ya se señaló, la Sociedad participó activamente de la producción de un imaginario visual nacional. Sus socios «solían desarrollar los temas urbanos con series de fotos, en lugar de una o dos tomas». ${ }^{55}$ Esto es de particular interés para el análisis del álbum de juegos infantiles: si bien la temática no se encuadra en el interés de construir una iconografía nacional que combinara motivos tradicionales rurales con el progreso urbano, sí puede asociarse con la intención de retratar tipos urbanos

\footnotetext{
51 Alexander \& Priamo, «Notas sobre la fotografía porteña del siglo XIX», 24.

52 Tell, El lado visible, 140 y 152.

53 Pese a ello, Priamo y Alexander documentan que al menos en algunos casos (como José de Iriondo, de Santa Fe) los negativos quedaron en su poder. Alexander \& Priamo, «Notas sobre la fotografía porteña del siglo XIX», 24.

${ }^{54}$ Tell, El lado visible, 228.

55 Abel Alexander \& Luis Priamo, «Notas sobre la fotografía porteña del siglo XIX», 25. La Sociedad realizaba concursos nacionales, que son un modo de poder identificar autorías. En el primer concurso en 1890 se pedía que se participe con al menos dos negativos y no más de cuatro: la idea era que el fotógrafo debía seleccionar sus registros atendiendo a su calidad como documento y como representación estética. Pero en años siguientes los concursantes enviaban colecciones con muchas fotografías, véase Verónica Tell, El lado visible, 258.
} 
y sociales, como la serie de vendedores ambulantes o servidores públicos. Según Tell, los socios de la SFAA «solían eludir los temas más áridos y menos atractivos como los conventillos, los barrios marginales, etc., lo cual se corresponde [...] con los intereses de difusión de las imágenes y la posición social del grueso del grupo». ${ }^{56}$ Un artículo que reseña la actividad de la Sociedad en 1897 lista los temas de las series de algunos socios, mencionando explícitamente el álbum de fotos de juegos de infancia y dándole inequívocamente la autoría a Juan M. Gutiérrez:

La valiosa y notable colección de negativos a cuya formación han contribuido todos los socios, se acrecienta cada día con nuevos trabajos, fotografías de panoramas, cuadros de costumbres, recuerdos históricos, tipos locales, marinas, y una variedad tan curiosa como artística de instantáneas obtenidas en todas las ciudades y regiones de la República, [...], porque á todos los rumbos han ido con sus máquinas y su intuición artísticas los Ayerza, Montes, Nunes, Sardá y Gutiérrez. Las instantáneas de viaje del Dr. José A. Ayerza, la colección de juegos infantiles del señor Gutiérrez, los cuadros campestres del Dr. Francisco Ayerza, [...] todas estas bellísimas fotografías, algunas de las cuales han exhornado [sic] las páginas de esta revista, constituyen por sí solas un tesoro artístico, y ponen de relieve los conocimientos, las aptitudes, la pasión y el gusto esquisito [sic] de estos distinguidos cultores del arte fotográfico, a cuya labor y constancia debe la Sociedad Fotográfica Argentina, su estado floreciente, y el arte fotográfico en general sus perfeccionamientos y adelantos. ${ }^{57}$

Tanto Luis Priamo como Verónica Tell, que han estudiado la acción de la SFAdeA, señalan que el enfoque fue desplazándose desde el interés documental al pictorialista; las fotos que se premiaron de niños y de ancianos, por ejemplo, tenían por lo general tonos románticos, imitando

\footnotetext{
56 Tell, El lado visible, 144. Al mismo tiempo, surgen las revistas ilustradas como Caras y Caretas, que sí incluyeron motivos como la protesta social y la violencia, y constituyen el fondo fotográfico más importante para las primeras décadas del siglo XX. Alexander \& Priamo, «Notas sobre la fotografía porteña del siglo XIX», 21 y 25.

57 Daguerre (seudónimo), «La Sociedad Fotográfica Argentina», Buenos Aires. Revista semanal ilustrada, Año III, No. 129 (26 de septiembre de 1897): 1; negritas de la autora.
} 
la composición pictórica del momento. ${ }^{58}$ En comparación con otros fotógrafos de la Sociedad que documentaban paisajes o tipos costumbristas, la opción de Juan M. Gutiérrez de fotografiar juegos infantiles en escenas colectivas, por lo general urbanas, se alinea con las teorías modernas de la infancia y la naturaleza humana antes que con la voluntad de reportero de la tradición nacional. Esto se analiza con más profundidad en el apartado siguiente.

\section{ANALIZANDO LA SERIE: HUELLAS INDEXICALES DE LAS VIDAS INFANTILES EN BUENOS AIRES, CA. 1890-1900}

¿Qué puede verse con relación a las características y el contenido de las fotos? Es claro que las imágenes abren múltiples líneas posibles de indagación, de las cuales en las páginas siguientes solamente se presentarán algunas que derivan de considerarlas en grupo y en la perspectiva de su contexto de producción de una iconografía nacional por parte de la SFAdeA.

Como documento histórico sobre la vida infantil, hay que destacar que estas fotografías tienen una calidad fotográfica inusual para los registros educativos, sobre todo porque son tomas que intentan reflejar, con suerte diversa, escenas cotidianas con un estilo casual y relajado, diferente a la solemnidad de las tomas de grupos escolares. Estas fotografías de escenas colectivas de juego se distancian de las tomas de estudio de las casas profesionales, que privilegian las poses de pie y representaciones estáticas de la niñez. ${ }^{59}$ En esa dirección, su colección de fotos se va alejando de los retratos de estudio y acercándose al fotoperiodismo que buscó registrar escenas y retratos colectivos. ${ }^{60}$ En ellas es evidente que hay una disposición de la escena por parte del fotógrafo, por ejemplo en la reiteración de tomas sobre el mismo juego, que repite escenarios y también grupos de niños; pero esa disposición o montaje

\footnotetext{
${ }^{58}$ Pueden verse las fotografías premiadas en el concurso de 1904 en «El primer acontecimiento artístico de 1904», La ilustración sudamericana. Revista Ilustrada de las Repúblicas Sud-Americanas, Año XII, no. 265-266 (enero 1904): 7-8.

59 Véase por ejemplo el análisis de fotografías brasileñas de infancia de la misma época en Natalia Brizuela, Fotografia e Império. Paisagens para um Brasil moderno (Sao Paulo: Companhia das Letras, 2012), 125-126.

${ }^{60}$ Gisèle Freund, La fotografía como documento social (México DF: Gustavo Gilli Editores, 1981), 95.
} 
no las invalida como fuentes sino que invita a indagar sobre la iconografía de infancia que se está produciendo.

Además de la intención de mostrar escenas infantiles con naturalidad y realismo - entendidas como estéticas datadas y no como representación de la realidad-, la segunda cualidad que las vuelve documentos históricos significativos es su condición de álbum, que permite analizarlas como serie, tratando de conectar las escenas que retratan, los actores y locaciones. En el abordaje elegido se buscó identificar algunos indicadores presentes en las imágenes, con una aproximación similar a la que toman Braster y Pozo Andrés en su estudio de fotografías en The New Era entre 1920 y 1939. ${ }^{61}$ Entre esos indicadores están los espacios que se muestran en las fotos, los sexos y las edades de los retratados.

En relación con los espacios mostrados en las fotos, hay un privilegio de espacios interiores (49 fotografías sobre 77 del álbum) sobre los exteriores (28). Los espacios interiores retratados son estables (uno - o quizás dos- patios internos que por sus columnas, puertas y ventanas parecen ser parte de una escuela); se reiteran las ventanas, las plantas y la decoración de una puerta de entrada. Los espacios exteriores, en cambio, son variados: hay calles empedradas, casas humildes, un parque público y un espacio semi-ruinoso de un baldío u obra en construcción (como pudo observarse en la figura 1). Muestran un espacio urbano donde convivían construcciones lujosas con espacios vacantes y descuidados, síntoma de una grilla urbana en plena redefinición. ${ }^{62}$ En conjunto, la imagen de la infancia es más urbana que «natural»; abundan las edificaciones y calles, y aunque se ven niñas rodeadas de plantas y flores, y ocasionalmente algunos niños pequeños con plantas, éstas tienen una presencia menor a la que gozaban en la iconografía romántica sobre la infancia. ${ }^{63}$

\footnotetext{
${ }^{61}$ Braster y Pozo Andrés, «La Escuela Nueva en Imágenes».

62 Adrián Gorelik, «Buenos Aires, 1850-1900: una ciudad en tránsito», en Buenos Aires, Memoria Antigua. Fotografías 1850-1900, ed. Luis Priamo (Buenos Aires: Fundación CEPPA Ediciones, 2018), 29-67.

${ }_{63}$ Anita Schorsch, Images of Childhood. An Illustrated Social History (New York: Mayflower Books, 1979), 94. Véase también el trabajo de Sandra Szir, Infancia y cultura visual. Los periódicos ilustrados para niños (1880-1910) (Buenos Aires: Miño y Dávila editores, 2007).
} 
Significativamente, aparecen en las imágenes ocho niños afro-argentinos, una proporción considerable si se toma en cuenta que en Buenos Aires este grupo poblacional venía en declive desde mediados del siglo XIX. ${ }^{64} 20$ fotografías muestran a niños ostensiblemente pobres, en ropas andrajosas o descalzos; otras 20 muestran grupos mezclados socialmente, en el que se ven sombreros costosos junto a vestuarios muy modestos o niños descalzos. Con relación al género, 35 fotografías incluyen grupos de niños exclusivamente, 28 sólo de niñas y 14 fotografías muestran grupos mixtos.

Estas fotografías se distancian de los retratos familiares del siglo XIX que componían escenas donde adultos y niños compartían actividades como jugar, conversar o leer libros. ${ }^{65} \mathrm{En}$ el álbum, sólo cinco fotografías incluyen adultos, generalmente en los bordes de la escena o manipulando animales, como en la riña de gallos. Lo que se busca es retratar, tanto como crear, un mundo infantil donde los adultos están al margen. Esto es consistente con lo que encuentran Burke y Grosvenor, y Braster y Pozo Andrés ${ }^{66}$ sobre las fotografías de la Escuela Nueva, aunque debe notarse que estas fotografías son al menos 20 años más antiguas. En cuanto a la edad, en 53 de ellas se observan grupos de niños de distintas edades, sobre todo las que se toman en exteriores, sugiriendo un espacio público donde edades y sectores sociales se mezclaban en juegos y actividades sociales, y donde los sectores de clase media y alta salían del confinamiento de sus casas para relacionarse con otros. Este es un aspecto interesante, confirmado por los estudios disponibles. Por ejemplo, Edgardo Ciafardo construye el siguiente relato a partir de notas periodísticas y autobiografías de escritores como Adolfo Bioy Casares y Conrado Nalé Roxlo:

Para obtener o defender cierta posición entre los compañeros de clase, era necesario luchar a golpes de puño, o resignarse a ser 'manteado' en los recreos. Si una discusión estallaba entre dos

\footnotetext{
${ }^{64}$ Mónica Quijada, Carmen Bernand y Arnd Schneider (eds.), Homogeneidad y Nación con un estudio de caso: Argentina, siglos XIX y XX (Madrid: CSIC, 2000).

${ }^{65}$ Schorsch, Images of Childhood. An Illustrated Social History, 87.

${ }_{66}$ Catherine Burke e Ian Grosvenor, «The Progressive Image in the History of Education: Stories of Two Schools», Visual Studies 22, no. 2 (2007): 159-163; Braster y Pozo Andrés, «La Escuela Nueva en Imágenes».
} 
compañeros de grados, lo usual era esperar la finalización de los cursos del día y dirigirse a un lugar apartado de la mirada de maestros y policías (una obra en construcción parece haber sido el lugar ideal) y dirimir peleando la diferencia. Para ello era necesario que los compañeros de grado estuvieran presentes en la justa a modo de testigos y jurados. Las reglas indicaban que los duelos «empezaban con las clásicas fórmulas de mojar la oreja o pisar la raya» y terminaban siempre «a primera sangre, es decir cuando a uno de los contendientes le sangraban las narices». ${ }^{67}$

En las fotos del álbum de la SFAdeA, la cámara se pone al mismo nivel que los niños; la mayor parte toma un plano de conjunto, que muestra la escena de juego con un pequeño marco del entorno. No hay tomas desde lo alto, pero tampoco primeros planos. Los cuerpos infantiles aparecen con distintas expresiones, a veces en movimiento y a veces sentados. Las fotos crean "pequeñas narrativas» ${ }^{68}$ que conectan a personas y lugares, fijando movimientos y retratando acciones. Se nota también lo que Alois Riegl llamaba «el valor de época», la sensación o sentimiento de estar observando un registro que tiene que ser legado a otras generaciones, que impacta visualmente y apela a las emociones. ${ }^{69} \mathrm{No}$ sorprende entonces que en una porción significativa de las escenas (24), hay niños que observan a otros niños jugar (y ser fotografiados) sin estar involucrados en la acción (figura 4).

\footnotetext{
${ }^{67}$ Edgardo Ciafardo, Los niños en la Ciudad de Buenos Aires, p. 26. Para estas descripciones, Ciafardo se basó en las notas de Enrique Herrero publicadas en la revista Buenos Aires junto con las fotografías. Véase Enrique Herrero, «Juegos Infantiles», en Buenos Aires. Revista Semanal Ilustrada III, no. 99 (28-2-1897): 14-15.

${ }^{68}$ Edwards, «Out and About: Photography, Topography, and Historical Imagination», 189.

${ }^{69}$ Edwards, «Out and About: Photography, Topography, and Historical Imagination», 185.
} 


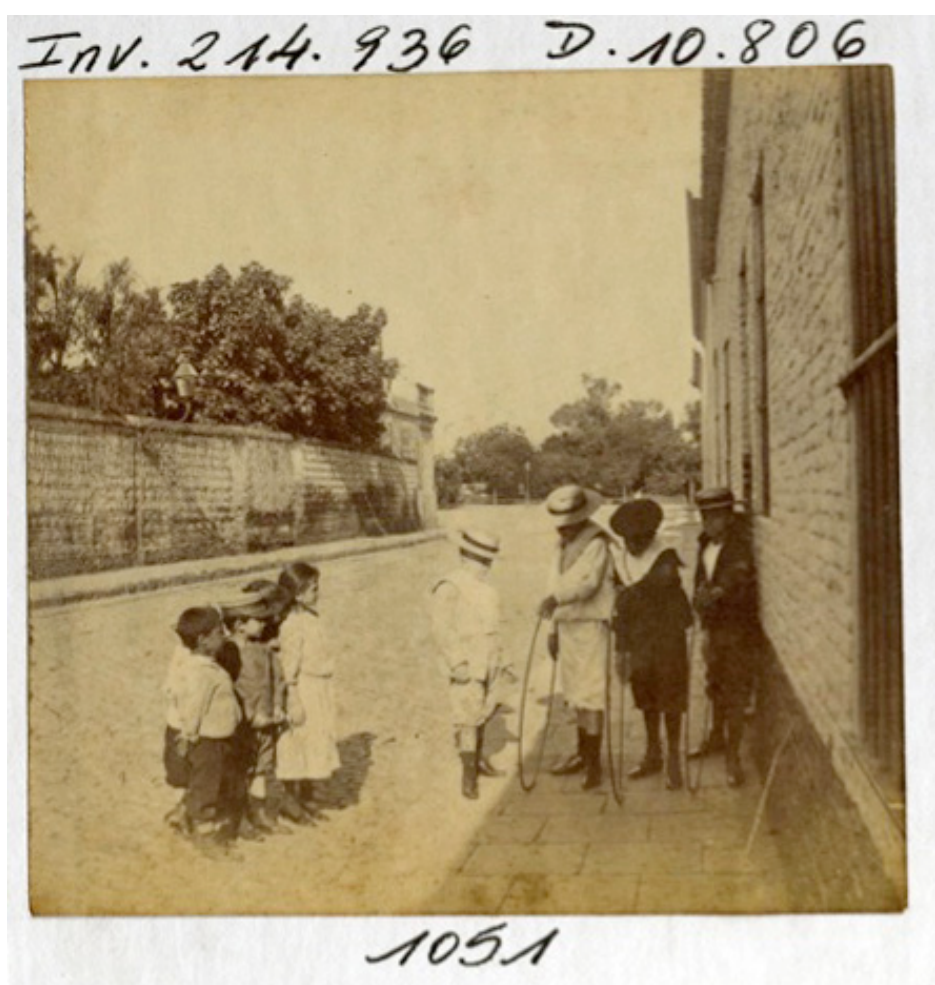

Figura 4. Argentina Archivo General de la Nación Dpto. Doc. Fotográficos, AR_AGN_DDF/Consulta_INV:214.936.

En la figura 4 vale la pena observar que, si bien los aros ya se usaban en la época medieval, no estaban especialmente destinados a los niños, igual que las canicas y los caballos de madera. ${ }^{70}$ Es hacia fines del siglo XIX que empiezan a considerarse como piezas lúdicas para la niñez, a la par que se van especificando espacios y reglas o roles para los juegos infantiles. Esta creciente especificación del juego puede verse en esta serie de imágenes. En términos de los juegos retratados, hay dos imágenes que contienen un barrilete; en un caso aparece una riña de gallos observada por niñas y niños, siendo la única imagen donde aparecen animales; dos fotografías retratan a un grupo de varones jugando a la rayuela en dos patios escolares distintos; otras dos a grupos de niños (uno de ellos mixto) jugando al Uñate; tres muestran a grupos de niños

${ }^{70}$ Schorsch, Images of Childhood. An Illustrated Social History, 83. 
jugando a Don Juan de las Casas; otras tres a niñas jugando al Martín Pescador; dos al Ta-te-ti o Tres en línea. En algunos casos, los juegos incluyen un alto despliegue físico que no involucra objetos (por ejemplo, caminar con las manos en un parque).

Pensando en los objetos, el rastro de la cultura material de la infancia en estas imágenes también provee pistas interesantes: se ve muy poca presencia de juguetes y de mercancías comerciales o industrializadas para el juego, que en general venían de Europa, sobre todo de Alemania, y eran privilegio de clase. ${ }^{71}$ Una sola de las 77 fotografías del álbum muestra un grupo mixto, con niñas jugando con muñecas y casas de muñecas, y un niño que utiliza un juguete de construcción, en lo que parece ser un patio de una casa (figura 5).

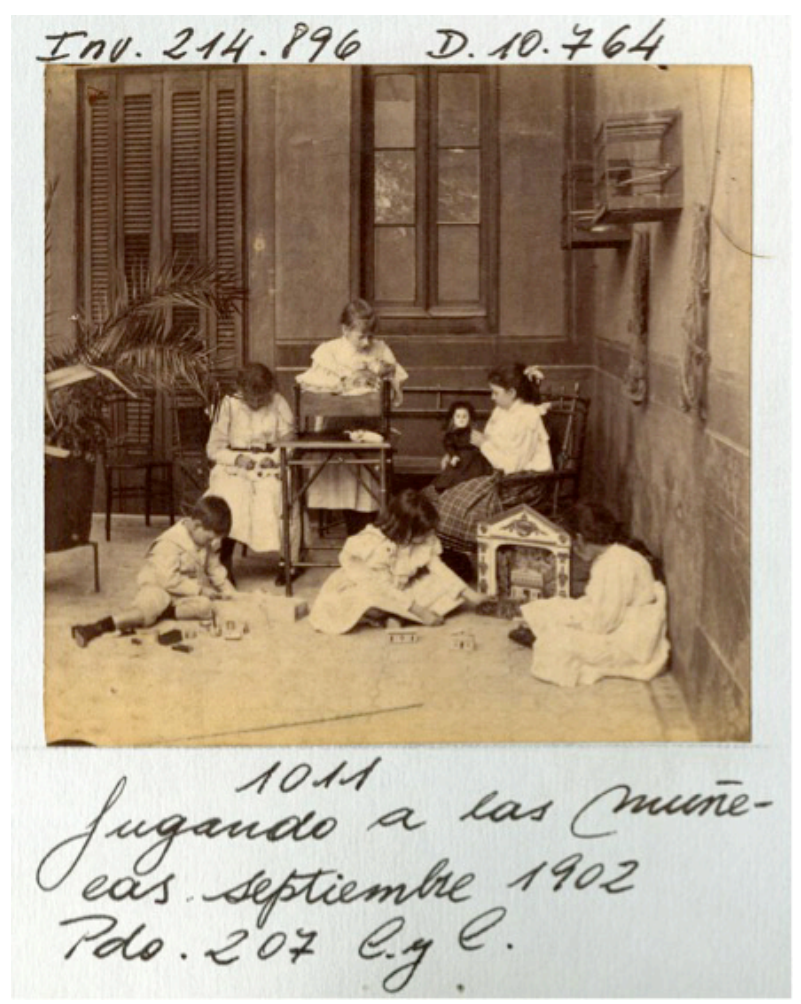

Figura 5. Argentina Archivo General de la Nación Dpto. Doc. Fotográficos, AR_AGN_DDF/Consulta_INV:214.896.

${ }_{71}$ Ciafardo, Los niños en la Ciudad de Buenos Aires. 
Siguiendo con el análisis de los rastros de la cultura material en las imágenes, puede verse que aún niños con vestuarios muy adornados y costosos juegan con juguetes improvisados de madera o cartón, o, como en el caso del sube y baja, en un artefacto armado con tablas dispuestas ocasionalmente (figura 6). Sólo 11 fotos muestran canicas, cuerdas o anillos. Por otra parte, puede observarse que los trajes de los varones reproducen el vestuario habitual en la época, especialmente el traje de marinero del niño que juega en la figura 6 y que también está presente en algunos niños de la figura $7 .{ }^{72}$

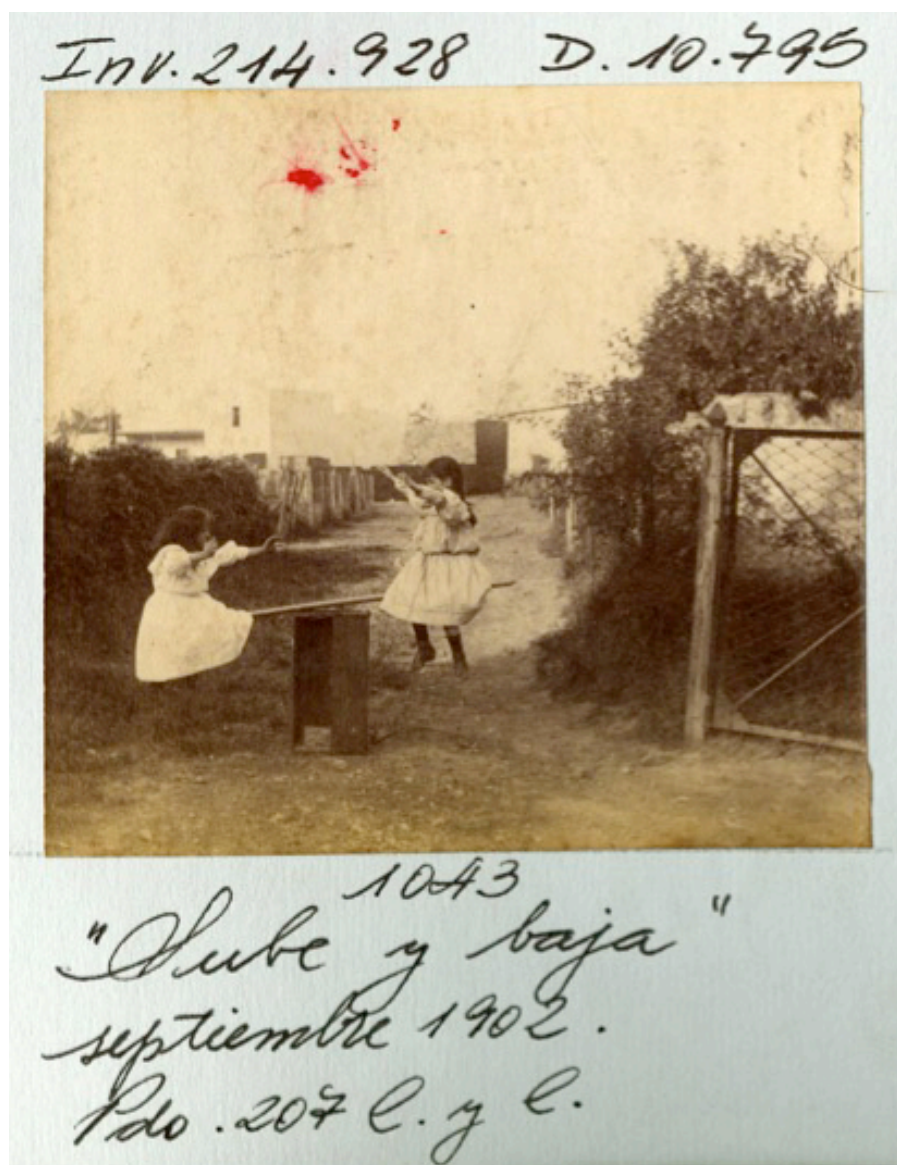

Figura 6. Argentina Archivo General de la Nación Dpto. Doc. Fotográficos, AR_AGN_DDF/Consulta_INV:214.928.

72 Clare Rose, Children's Clothes (London: B.T. Batsford Limited, 1989). 
Además de las locaciones, que en varias fotografías parecen remitir a un espacio escolar (por ejemplo, por la presencia de una mujer adulta o de un patio que da a habitaciones que parecen aulas), hay otras huellas de la presencia de la escuela en la vida infantil, que en la ciudad de Buenos Aires alcanzaba a cerca del $60 \%$ de la población en edad escolar. ${ }^{73}$ En ocho fotos se ven cuadernos, libros y mochilas o carteras escolares, en general puestos al costado mientras se desarrollan los juegos (figura 7).

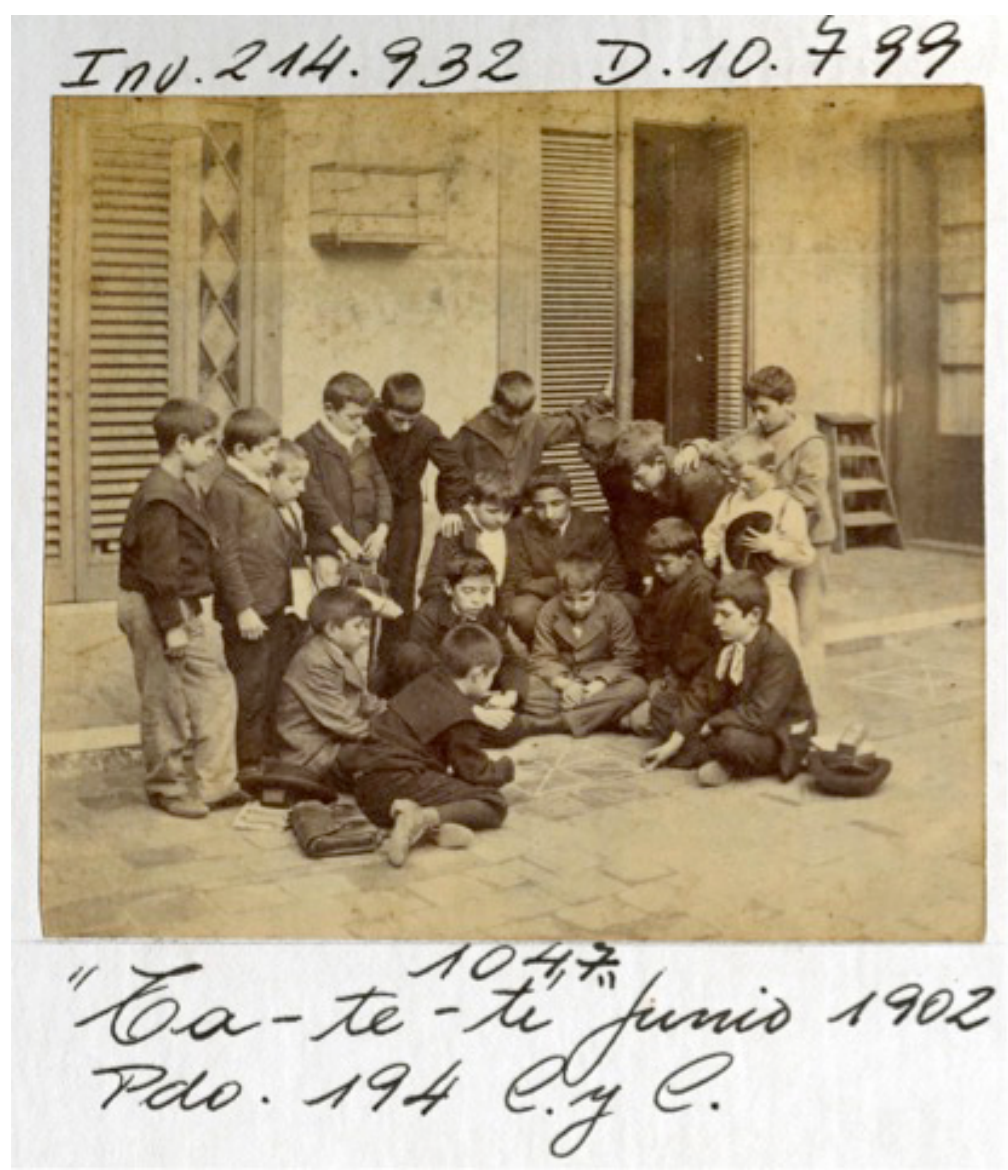

Figura 7. Ta-te-Ti. Argentina Archivo General de la Nación Dpto. Doc. Fotográficos, AR_AGN_DDF/Consulta_INV:214.932.

\footnotetext{
${ }^{73}$ Según el Censo nacional de población de 1895, el porcentaje de alumnos que asistían a la escuela en la ciudad de Buenos Aires era del 57,7\%, muy superior al promedio nacional del 29,6\%. Véase Susana Di Pietro y Ariel Tófalo (coords.), La situación educativa a través de los Censos Nacionales de Población (Buenos Aires: Dirección General de Evaluación de la Calidad Educativa, 2013), 15.
} 
Al respecto, cabe notar que la presencia de la cultura letrada es mínima: además de estas ocho fotos que muestran carteras escolares con libros, hay una sola imagen (ya presentada en la figura 1) que muestra una escena colectiva con una presencia notoria de libros en un espacio exterior. Una fotografía que muestra a un grupo mixto titulada "Contando cuentos» (publicada en Caras y Caretas como «Haciendo Cuentas») no muestra ningún libro. En esa dirección, podría decirse que esta serie de imágenes se distancia de la presentación del niño lector como ideal de infancia, ${ }^{74}$ y pone el acento en otros rasgos de las prácticas infantiles que apuntan al juego colectivo, la convivencia de los cuerpos y la asunción de otros roles.

¿Qué iconografía sobre la infancia busca producir esta serie de fotografías? Las imágenes de infancia parecen ser más modernas que otras concepciones vigentes en la época. ${ }^{75}$ Por un lado, puede notarse que sigue operando la distinción de actividades por sexo, y la mayor parte de las imágenes retratan a grupos de un solo sexo. Pero junto con las numerosas fotografías que muestran las proezas físicas y la pelea entre los varones, también se ven escenas como la del juego con aros de la figura $4 \mathrm{u}$ otras donde los niños pequeños participan de bailes que no serían del agrado de quienes temían la feminización de los varones. Pueden contrastarse estas fotos con lo que un distinguido pedagogo como Rodolfo Senet decía: «nada es más triste que ver a los varones jugando con aros o saltando las cuerdas como niñas [...], en fin, a los que se llamaba mariquitas en mis tiempos de niño».76

Por otro lado, pueden verse escenas que luego se volverán peligrosas o serán prohibidas: la riña de gallos o niños que fuman (figura 1). En las notas de Caras y Caretas, se mencionan «juegos violentos» que, sin embargo,

\footnotetext{
${ }^{74}$ Véase el trabajo de Beatriz Alcubierre Moya, Ciudadanos del futuro. Una historia de las publicaciones para niños en el siglo XIX mexicano (Ciudad de México: El Colegio de México/Universidad Autónoma del Estado de Morelos, 2008).

${ }^{75}$ Nótese por ejemplo lo que se señala en la revista mexicana La edad feliz en 1873: «Los juegos y ejercicios que se permitan a los niños deben ser adecuados a su edad y a su sexo. Debe procurarse que los hombres desde la primera edad sean fuertes, ágiles y animosos, combatiendo vigorosamente cualquier inclinación al afeminamiento por leve que sea. A las niñas, por el contrario, se les debe inclinar a la modestia, el recato y a la ternura» (citado por Beatriz Alcubierre Moya, Ciudadanos del futuro, 192).

${ }^{76}$ Rodolfo Senet, «El niño de esta época» (1906), citado en Ciafardo, Los niños en la Ciudad de Buenos Aires, 25.
} 
son considerados como positivos porque permiten a los varones desarrollar la destreza y fuerza física. ${ }^{77}$ También se refieren juegos que involucran apuestas en dinero, que reúnen a «verdaderas nubes de muchachos» (varones) que, cuando grandes, seguirán desarrollando en actividades como «la afición por el hipódromo». ${ }^{78}$ Las niñas también se muestran en juegos donde «corren y chillan», lo cual es positivo para su educación física aunque no sea "cómodo para sus padres». ${ }^{79}$ Hay una distancia evidente de esta iconografía respecto a la cruzada que por esos mismos años los puritanos estaban llevando adelante contra el juego infantil en países como Inglaterra y Estados Unidos. ${ }^{80}$

En síntesis, puede decirse que el álbum de la SFAdeA construye una iconografía de infancia que juega con tranquilidad y naturalidad, todavía no sometida a la comercialización y mercantilización por vía de los juguetes, pero ya indicativa de una diferenciación y especificación de las prácticas y espacios infantiles en los cuales el juego tiene un rol definitorio. En esa dirección, pone en evidencia la reconsideración del juego no como pérdida de tiempo sino, siguiendo al historiador norteamericano Stephen Kline, como actividad formativa, como «el trabajo de la infancia», equivalente moral del trabajo adulto. ${ }^{81}$ En relación con la escuela, la inclusión de escenas de juego dentro de espacios escolares parece reafirmar que el juego tiene un valor pedagógico o educativo, y que no es antitético. Las imágenes traducen estas concepciones en los rostros concentrados, los cuerpos con sus músculos dispuestos, y la comunión o conjunción de intereses entre niños que no necesitan de la orientación adulta. Estas imágenes parecen querer decir que el juego es lo propio de la infancia y que hay que tomarlo en serio, como los mismos niños.

\footnotetext{
77 Figarillo, «La payana-El rescate-Las plumas», Caras y Caretas V, no. 203 (23 de agosto de 1902): 62.

${ }^{78}$ Figarillo, «Hoyo y Quema- Ta-te-ti - La rayuela», Caras y Caretas V, no. 194 (21 de junio de 1902): 60.

${ }^{79}$ Figarillo, «Sir Roger-Las esquinitas-Abuelita, ¿qué horas son?», Caras y Caretas V, no. 190 (24 de mayo de 1902): 67.

80 Schorsch, Images of Childhood. An Illustrated Social History, 77.

${ }_{81}$ «Los niños de la calle eran llevados al parque para que adquirieran el gusto de una actividad colectiva organizada. El juego estructurado y el deporte eran altamente recomendados como modos de preparar a los niños para una sociedad competitiva y para crear un espacio de encuentro y negociación entre clases. Los juegos infantiles en los que los niños simulaban ser animales fueron recomendados para que los niños de la clase obrera aprendieran conductas infantiles apropiadas». Stephen Kline, "The Making of Children's Culture», en The Children's Culture Reader, ed. Henry Jenkins (New York: New York University Press, 1998), 100.
} 


\section{CONSIDERACIONES FINALES: LAS NIÑAS QUE NOS MIRAN}

Hay un rasgo de esta serie que es también muy interesante: estas fotografías de niños y niñas no muestran una infancia particularmente feliz o divertida. No abundan las sonrisas ni los movimientos libres, salvo en algunas pocas secuencias. En la historia de los medios, la aparición de la imagen de la infancia divertida parece haber emergido algo después, en las décadas de 1920 y $1930 .{ }^{82}$ Pero la ausencia de caras risueñas habla de una rigidez de los cuerpos infantiles que probablemente se deba, antes que a un sufrimiento de la infancia en esa época, a la presencia de la cámara y del fotógrafo; aunque colocados al mismo nivel que los niños, pareciera que ellos no hubieran podido desprenderse de la desigualdad de clase, generacional y tecnológica que su presencia instauraba.

Es allí donde la noción de la fotografía como la huella de un encuentro cobra relevancia. La imagen no es solamente lo que el fotógrafo quiso hacer: en esos gestos adustos y en esa fijeza de los cuerpos, pueden encontrarse - quizás - rastros del tedio o el rechazo a coreografías o disposiciones varias veces ensayadas, o de la resistencia a las órdenes del joven fotógrafo rico y poderoso. Pero también pueden verse los efectos que empiezan a tener las cámaras que convierten a los sujetos en objetos, investidos de una cierta impostura al convertirse en signos visuales intercambiables. ${ }^{83}$

Entre las fotografías de esta serie, hay una imagen en particular que muestra el cruce de miradas entre el fotógrafo y las niñas (Figs. 8 y 9), que convoca, más claramente que otras, a imaginar el momento en que las fotografías fueron hechas.

\footnotetext{
82 Véase Sarah Wolfenstein, «Fun Morality: An Analysis of Recent American Child-Training Literature», en Childhood in contemporary cultures, eds. Margaret Mead \& Sarah Wolfenstein (Chicago and London: The University of Chicago Press, 1955), 179-203.

83 Decía Barthes: «La foto-retrato es una empalizada de fuerzas. Cuatro imaginarios se cruzan, se afrontan, se deforman. Ante el objetivo soy a la vez: aquel que creo ser, aquel que quisiera que crean, aquel que el fotógrafo cree que soy y aquel de quien se sirve para exhibir su arte. Dicho de otro modo, una acción curiosa: no ceso de imitarme, y es por ello que cada vez que me hago (que me dejo) fotografiar, me roza indefectiblemente una sensación de inautenticidad, de impostura a veces». Roland Barthes, La cámara lúcida. Nota sobre la fotografía (Barcelona: Paidós, 1989), 41-42.
} 

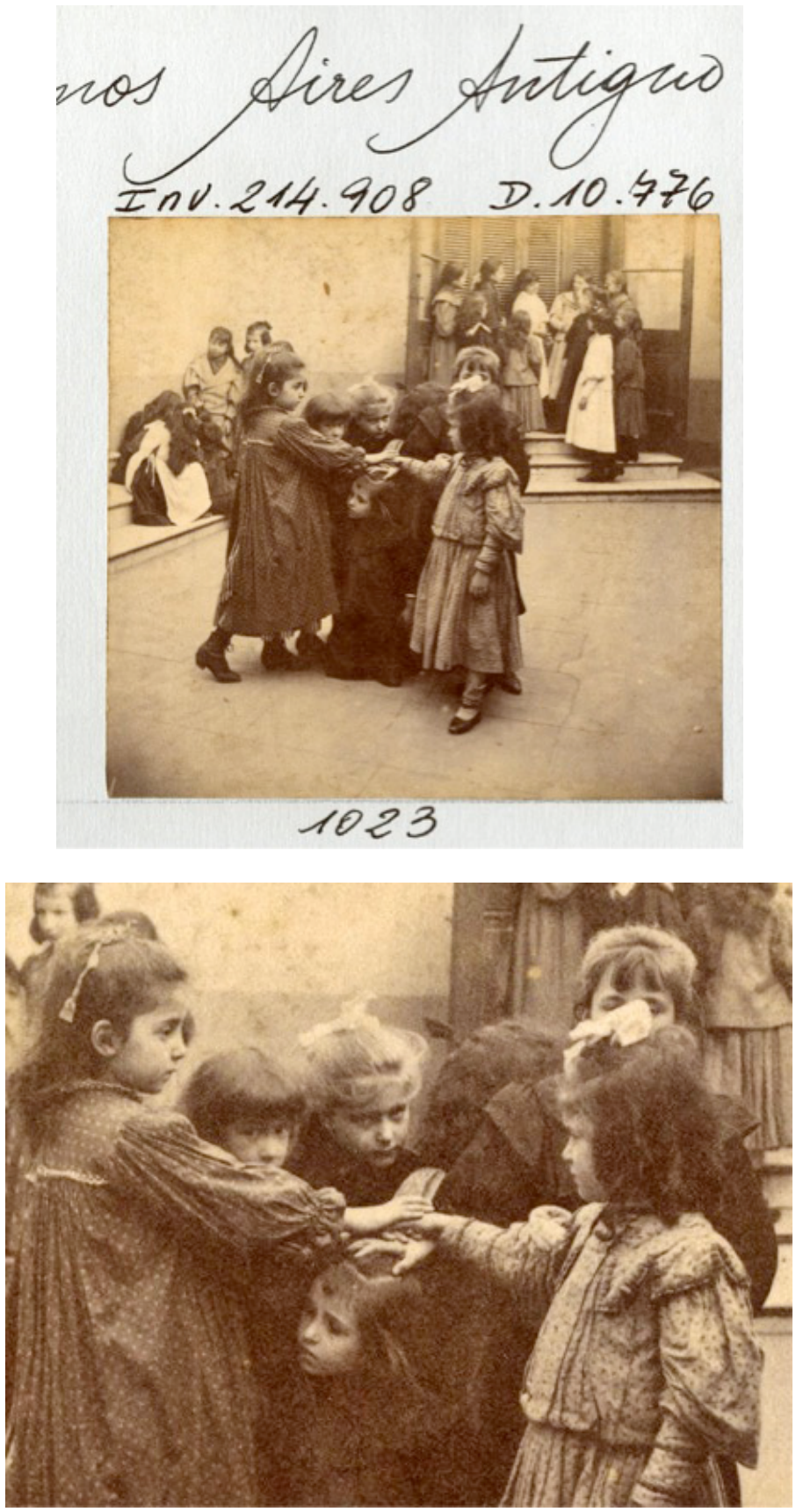

Figuras 8 y 9 (detalle). Argentina Archivo General de la Nación Dpto. Doc. Fotográficos, AR_AGN_DDF/ Consulta_INV:214.908. 
Las miradas de las niñas permiten sentir, aunque sea por un instante, la herida del tiempo de la que habla Arlette Farge. ${ }^{84}$ ¿Qué habrán sentido estas niñas en ese instante? ¿Cómo habrá intersectado sus vidas este momento de ser fotografiadas? Son preguntas para las que no hay respuesta, pero que ayudan a ver la importancia de rescatar del archivo donde están enterradas algunas piezas para intentar singularizarlas, buscando entender el flujo de experiencias, artefactos y cuerpos en el que fueron producidas y procurando hacer también una historia de las miradas, como pedía Barthes. Ese rescate va en contra de la des-identificación que promueven muchos archivos visuales, que relegan las fotos a meros ejemplos de estereotipos o categorías predefinidas. Al revés, habría que intentar, en el trabajo con los documentos fotográficos, conectar con lo que ofrece la fotografía de encuentro con la alteridad, con vidas pasadas que no se terminan de comprender del todo, pero que muestran que el pasado contenía otros futuros. En el caso de esta serie, se hace evidente que había otras posibilidades sobre la posibilidad de los niños, y particularmente de las niñas, de devolverle la mirada al fotógrafo, pero también sobre los juguetes como industria, los límites entre juegos permitidos y prohibidos, la violencia en el juego, los bordes entre lo femenino y lo masculino, el uso del dinero por los niños, y las mezclas y convivencias en el espacio público y el escolar.

Las miradas que devuelven las niñas no solamente se cruzan con la del fotógrafo sino también con los investigadores de hoy, y eso permite atender también a la demanda ética que plantea el trabajo con estas imágenes. En el tiempo de lo digital, de la circulación amnésica y voraz de las imágenes, hay que insistir en un acto de sublevación, como historiadores, a estos procesos gigantescos de serializar la fotografía y de avanzar en la desidentificación. Contra eso, habría que afirmar la singularidad del encuentro con la fotografía, singular por el objeto fotográfico y también por el momento en que cruza con el presente de quien la mira.

Esa demanda ética también pasa por prestarle atención a esas miradas que conducen a otro tiempo y lugar. Dice Agamben, comentando a Benjamin:

Incluso si la persona fotografiada estuviera hoy del todo olvidada, incluso si su nombre estuviera borrado para siempre de la

\footnotetext{
${ }^{84}$ Farge, «Le temps logé en la photographie. À partir de Barthes et Kracauer».
} 
memoria de los hombres, incluso si a pesar de todo eso -o quizás, precisamente por ello- esa persona, ese rostro exige su nombre, exige no ser olvidado. ${ }^{85}$

Aunque el nombre de esas niñas es prácticamente imposible de encontrar, en el acercamiento a las fotografías habría que dejarse alcanzar por su mirada, escucharla con otros aparatos (otros golpecitos de los dedos, otros estetoscopios), para que diga algo de lo que pudo haber sido su experiencia humana, la de ellas y la de tantos otros que no habría que olvidar. Benjamin decía que, frente a la tempestad que sopla desde la tierra del olvido, el único ataque de caballería posible era estudiar, que equivale a acercarse, darse el tiempo, frecuentar un texto o un registro del pasado. El trabajo con el álbum de imágenes de infancia muestra la importancia de que la investigación histórico-educativa se permita, a través de la fotografía, la oportunidad de un encuentro con otras historias y otras experiencias, darse el tiempo de estudiar los registros del pasado con cuidado y profundidad, para habilitar también otras políticas de archivo y de memoria en la educación.

\section{Nota sobre la autora}

InES Dussel es profesora investigadora del Departamento de Investigaciones Educativas del CINVESTAV-IPN, México. Miembro del Sistema Nacional de Investigadores (SNI) de México, Categoría III. Fue directora del Área Educación de FLACSO/Argentina entre 2001 y 2008. Es doctora en Educación (Ph.D.) por la Universidad de Wisconsin-Madison. Su formación de base es en Ciencias de la Educación, en la Universidad de Buenos Aires, y cuenta también con una maestría en Ciencias Sociales de FLACSO/Argentina. Es miembro de la International Academy of Education (IAE). Actualmente es Secretaria de la ISCHE (International Standing Conference for the History of Education). Ha escrito diez libros, compilado cuatro, y publicado más de 180 artículos y capítulos de libros en medios reconocidos internacionalmente, en seis idiomas. Fue invitada a dar conferencias y cursos en la Universidad de París 8, Universidad de Luxemburgo, Universidad Humboldt, Universidad de Tampere, Universidad de Wisconsin-Madison, Universidad de Melbourne,

\footnotetext{
85 Giorgio Agamben, Profanaciones (Buenos Aires: Adriana Hidalgo, 2005), 33.
} 
Universidad Complutense de Madrid, Universidad de Granada, Universidad de Girona, PUC-Sao Paulo y UDESC (Brasil), entre otras. Participa en el comité académico de más de 20 revistas de calidad internacional de América Latina, Europa, Norteamérica y Australia. Recibió en 2018 el Humboldt Research Award, otorgado por la Alexander von Humboldt Stiftung (Alemania) en reconocimiento a su trayectoria académica.

\section{Publicaciones periódicas}

Buenos Aires. Revista Semanal Ilustrada (1896-1899).

Caras y Caretas (1902-1903).

La Ilustración Sudamericana. Revista Ilustrada de las Repúblicas Sud-Americanas (1904)

\section{REFERENCIAS}

Agamben, Giorgio. Profanaciones. Buenos Aires: Adriana Hidalgo, 2005.

Aguayo, Fernando y Alejandra Padilla Pola. «Fotografía y ciudad». En «Instantáneas» de la Ciudad de México. Un álbum de 1883-1884, editado por Alicia Salmerón y Fernando Aguayo, 38-55. Ciudad de México: Instituto Mora/ Universidad Autónoma Metropolitana-Cuajimalpa, 2013.

Alcubierre Moya, Beatriz. Ciudadanos del futuro. Una historia de las publicaciones para niños en el siglo XIX mexicano. Ciudad de México: El Colegio de México/Universidad Autónoma del Estado de Morelos, 2008.

Alexander, Abel \& Luis Priamo. «Notas sobre la fotografía porteña del siglo XIX». En Buenos Aires, Memoria Antigua. Fotografías 1850-1900, editado por Luis Priamo, 9-27. Buenos Aires: Fundación CEPPA Ediciones, 2018. Bajac, Quentin. La fotografía. La época moderna, 1880-1960. Barcelona: Blume, 2015.

Barthes, Roland. La cámara lúcida. Nota sobre la fotografía. Barcelona: Paidós, 1989. Benjamin, Walter. «Franz Kafka. On the Tenth Anniversary of his Death». En Illuminations. Essays and Reflections, 111-140. New York: Schocken Books, 1968.

Berger, John. «Appearances». En Another way of telling, editado por John Berger \& Jean Mohr, 81-129. New York: Vintage Books, 1995.

Braster, Sjaak y María del Mar Pozo Andrés. «La Escuela Nueva en Imágenes: Fotografía y Propaganda en The New Era (1920-1939)». Historia y Memoria de la Educación 8 (2018): 97-145.

Brizuela, Natalia. Fotografia e Império. Paisagens para um Brasil moderno. Sao Paulo: Companhia das Letras, 2012. 
Burke, Catherine e Ian Grosvenor. «The Progressive Image in the History of Education: Stories of Two Schools». Visual Studies 22, no. 2 (2007): 159163.

Caimari, Lila. La vida en el archivo. Goces, tedios y desvios en el oficio de la historia. Buenos Aires: Siglo XXI Editores, 2017.

Ciafardo, Edgardo. Los niños en la Ciudad de Buenos Aires (1890-1910). Buenos Aires: CEAL, 1992.

Daston, Lorraine \& Peter Galison. Objectivity. New York: Zone Books, 2007.

De Certeau, Michel. La escritura de la historia. Ciudad de México: Universidad Iberoamericana, 2006.

Di Pietro, Susana y Ariel Tófalo (coord.). La situación educativa a través de los Censos Nacionales de Población. Buenos Aires: Dirección General de Evaluación de la Calidad Educativa, 2013.

Didi-Huberman, Georges. "L'image brûle». En Penser par les images, Laurent Zimmermann, Georges Didi Huberman, et al., 11-52. Nantes: Editions Cécile Defaut, 2006.

Doane, Mary-Ann. The Emergence of Cinematic Time. Modernity, Contigency, the Archive. Cambridge, MA: Harvard University Press, 2002.

Dussel, Inés \& Karin Priem. «The visual in histories of education: A Reappraisal». Paedagogica Historica 53, no. 6 (2017): 641-649.

Edwards, Elizabeth. The Camera as Historian. Amateur Photography and Historical Imagination, 1885-1918. Durham, NC: Duke University Press, 2012.

Edwards, Elizabeth. «Out and About: Photography, Topography, and Historical Imagination». In Double Exposure: Memory and Photography, edited by Olga Shevchencko, 185-209. London: Transaction Press, 2014.

Edwards, Elizabeth. «Photography: A Strong History?». En Photo Archives and the Idea of the Nation, editado por Constanza Caraffa \& Tiziana Serena, 32129. Berlin: Walter De Gruyter, 2015.

Farge, Arlette. «Le temps logé en la photographie. À partir de Barthes et Kracauer». Intermédialités 7 (2006): 205-213.

Freund, Gisèle. La fotografía como documento social. México DF: Gustavo Gilli Editores, 1981.

Garat, Anne-Marie. Found Photography. London: Thames and Hudson, 2013.

Génette, Gérard. Umbrales. México DF: Siglo XXI, 2001.

Gervais, Thierry. «Witness to War: The Uses of Photography in the Illustrated Press, 1855-1904». Journal of Visual Culture 9, no. 3 (2010): 370-384.

Gómez, Juan. La Fotografía en la Argentina. Su Historia y Evolución en el Siglo XIX, 1840-1899. Temperley: Abadía Ediciones, 1986.

Gorelik, Adrián. «Buenos Aires, 1850-1900: una ciudad en tránsito». En Buenos Aires, Memoria Antigua. Fotografías 1850-1900, editado por Luis Priamo, 29-67. Buenos Aires: Fundación CEPPA Ediciones, 2018. 
Gunning, Tom. «What's the Point of an Índex? Or, Faking Photographs». En Still Moving. Between Cinema and Photography edited by Karen Beckman \& Jean Ma, 23-40. Durham, NC \& London: Duke University Press, 2008.

Hernández, Santos S.J. Juegos de los niños en las escuelas y colegios. Madrid: Editorial Saturnino Calleja, 1876.

Hunt, Lynn \& Vanessa Schwartz. "Capturing the Moment: Images and Eyewitnessing in History». Journal of Visual Culture 9, no. 3 (2010): 259-271.

Kline, Stephen. «The Making of Children's Culture». En The Children's Culture Reader, edited by Henry Jenkins, 95-109. New York: New York University Press, 1998.

Lindeperg, Sylvie. La voie des images. Quatre histoires de tournage au printemps-été 1944. Paris: Verdier, 2013.

Londe, Alberto. La fotografía moderna. Práctica y aplicaciones. Madrid: Fuentes y Capdeville, 1889. Edición facsimilar- Sevilla: Extramuros, 2007.

Mirás, Marta. Imágenes del espacio público. Buenos Aires 1900. Buenos Aires: Instituto de Arte Americano e Investigaciones Estéticas, 2001.

Mirzoeff, Nicholas. How to See the World. A Pelican Introduction. London: Penguin Books, 2015.

Nóvoa, António. «Ways of Saying, Ways of Seeing: Public Images of Teachers (19th- 20th Centuries)». Paedagogica Historica 36, no, 1 (2000): 20-52.

Pererneau, Marcos. "Construcción de la referencia». En Antología de Argumentos teatrales en Argentina, 2003-2013, 11-21. Buenos Aires: Libretto, 2015.

Pestarino, Julieta. «La imagen fotográfica bajo la mirada antropológica. El caso de la Sociedad Fotográfica Argentina de Aficionados». XI Jornadas de Sociología. Facultad de Ciencias Sociales, Universidad de Buenos Aires, Buenos Aires, 2015.

Poole, Deborah. Vision, Race and Modernity. A Visual Economy of the Andean Image World. Princeton, NJ: Princeton University Press, 1997.

Priamo, Luis. «La Sociedad Fotográfica Argentina de Aficionados y sus fotografías nacionales», ponencia presentada en I Encontro de História da Fotografía Latino-Americana Gilberto Ferrez, Río de Janeiro, Brazil, 1997.

Quijada, Mónica, Carmen Bernand y Arnd Schneider (eds.). Homogeneidad y Nación con un estudio de caso: Argentina, siglos XIX y XX. Madrid: CSIC, 2000.

Rose, Clare. Children's Clothes. London: B.T. Batsford Limited, 1989.

Schorsch, Anita. Images of Childhood. An Illustrated Social History. New York: Mayflower Books, 1979.

Spencer Sternberger, Paul. Between Amateur and Aesthete: The Legitimation of Photography as Art in America, 1880-1900. Albuquerque, NM: University of New Mexico Press, 2002. 
Szendy, Peter. En lo profundo de un oído. Una estética de la escucha. Santiago de Chile: Ediciones Metales Pesados, 2010.

Szir, Sandra M. Infancia y cultura visual. Los periódicos ilustrados para niños (1880-1910). Buenos Aires: Miño y Dávila editores, 2007.

Tell, Verónica. «Gentlemen, gauchos y modernización. Una lectura del proyecto de la Sociedad Fotográfica Argentina de Aficionados». Caiana. Revista de Historia del Arte y Cultura Visual del Centro Argentino de Investigadores de Arte (CAIA) 3 (2013): 1-19. http://caiana.caia.org.ar/template/caiana.php?pa$\mathrm{g}=$ articles/article_2.php\&obj=110\&vol=3.

Tell, Verónica. El lado visible. Fotografía y progreso en la Argentina a fines del siglo XIX. San Martín: UNSAM EDITA, 2017.

Wolfenstein, Sarah. «Fun Morality: An Analysis of Recent American Child-Training Literature». En Childhood in contemporary cultures, editado por Margaret Mead \& Sarah Wolfenstein, 179-203.Chicago and London: The University of Chicago Press, 1995.

Yacavone, Kathryn. Benjamin, Barthes, and the Singularity of Photography. New York \& London: Bloomsbury, 2013. 